Hintze, H.C. Ecoturismo na cultura de consumo: possibilidade de Educação Ambiental ou espetáculo?

Revista Brasileira de Ecoturismo, São Paulo, v.2, n.1, 2009, pp.57-100.

\title{
Ecoturismo na cultura de consumo: possibilidade de Educação Ambiental ou espetáculo? Hélio César Hintze
}

\section{RESUMO}

Este trabalho busca averiguar a existência de uma preocupação com a Educação Ambiental (e quais os princípios que a regem) nas atividades e pacotes 'ecoturísticos' comercializados pelo mercado. Para atingir tal objetivo, procurou-se conhecer o termo Ecoturismo a partir das perspectivas da cultura de consumo e da sociedade do espetáculo e sob tal enfoque discutir suas relações com temas como turismo e consumo, natureza e educação ambiental; buscouse também identificar as bases filosóficas do trabalho ecoturístico (particularmente em sua relação com a questão da educação ambiental) desenvolvido pelas operadoras de tais atividades; e por fim, realizar crítica conceitual acerca das relações entre os assuntos abordados por este estudo. Foram entrevistadas 03 operadoras do mercado ecoturístico e 03 pesquisadores de áreas relacionadas aos temas propostos. O texto foi produzido a partir das informações obtidas por levantamento bibliográfico em diálogo com as opiniões obtidas nas entrevistas no trabalho de campo. Com base nos estudos realizados foi considerado que o Ecoturismo como atividade de mercado é pouco utilizado para a disseminação da consciência ambientalista por conta das operadoras terem uma visão da educação ambiental que a aproxima da educação formal e que tal característica não deve ser integrada às atividades turísticas momentos de diversão e lazer; e neste sentido ainda constatou-se também que o Ecoturismo é uma atividade que pode produzir subjetividade consumista nos participantes do processo assim como reafirmar o tempo espetacular do capital.

PALAVRAS-CHAVE: Sociedade do espetáculo; Ecoturismo; Educação ambiental

\section{Ecotourism in the culture of consumption: possibility of Environmental Education or spectacle?}

\section{ABSTRACT}

This work has investigated the existence of a preoccupation with the Environmental Education (and its leading principles) in the activities and ecotourism packages traded on the market; to achieve such aim it has searched to understand the term ecotourism from the culture of consumption and society of the spectacle perspective, and under such view, to discuss its relation with themes such as tourism and consumption, nature and environmental education; It has searched to identify the philosophical basis of the ecotourism work (particularly in its relation with the environmental education matter) developed by the operators of such activities; and finally, to do a conceptual critic on the issues considered on this essay. 03 operators of the ecotourism market and 03 researchers of areas related to the theme here proposed were interviewed. This essay was written based on the information collected through bibliographic research and opinions gathered in the interviews on the field work. Based on these studies It was considered that the ecotourism as a market activity isn't much used to spread the environmental awareness due to the fact that the operators have a view of environmental education close to a formal education and such characteristic shouldn't be integrated to the tourism activities - fun moments and leisure; it was also noticed that the ecotourism is an activity that may evoke consumption patterns among its participants and reassures the capital's spectacular time.

KEY-WORDS: Society of the spectacle; Ecotourism; Environmental Education 


\section{INTRODUÇÃO}

Este artigo apresenta estudo sobre o Ecoturismo - sua origem, contexto e significado - e suas relações na cultura de consumo. Seus números de mercado alcançaram a casa dos trinta por cento (30\%) ao ano segundo estatísticas de seu desenvolvimento mundial e oficial (WEARING; NEIL, 2001). São os maiores índices do turismo. Isso contudo, não ser acompanhado por uma crescente preocupação com a Educação Ambiental. Perguntamos: quais os limites de uma Educação Ambiental exercitada em práticas mercadológicas do Ecoturismo na cultura de consumo?

O Ecoturismo é um conceito polissêmico de difícil compreensão e fácil manipulação por parte dos interessados em seu estudo conceitual e práticas de mercado. O objetivo deste estudo é averiguar a existência de uma preocupação com a Educação Ambiental (e quais os princípios que a regem) nas atividades e pacotes ecoturísticos comercializados pelo mercado. Para tanto, são desenvolvidos os seguintes objetivos específicos: (1) Levantamento bibliográfico referente ao Ecoturismo e discuti-lo como mercadoria e como espetáculo. (2) Identificar a preocupação com a Educação Ambiental nas atividades ecoturísticas desenvolvidas pelas operadoras de mercado. (3) Crítica conceitual acerca das relações entre os assuntos abordados.

Para tanto foi realizado levantamento bibliográfico dos principais temas abordados. Entre os meses de maio e dezembro do ano de 2007 foi realizada pesquisa qualitativa com entrevista a 03 pesquisadores da área de educação e Educação Ambiental (movimento ambientalista) e 03 operadoras que se intitulam ecoturísticas ou ao menos comercializem pacotes intitulados ecoturísticos. Para as operadoras, fizemos as seguintes questões:

(1) Para que levar pessoas (crianças, jovens, adultos, idosos) para visitar a natureza? (2) Sua empresa vê diferenças entre Ecoturismo e turismo 'convencional'? (3) Como sua empresa vê a relação entre Ecoturismo e Educação Ambiental? (4) Quanto ao planejamento das atividades de Educação Ambiental nas atividades ecoturísticas comercializadas por sua empresa, há alguma fundamentação teórica para o trabalho de campo? (5) Como são trabalhadas as questões da Educação Ambiental pelos condutores de grupos junto aos turistas? Apresentamos ao final, crítica conceitual das relações entre os assuntos abordados, questionando o conceito alternativo do Ecoturismo em relação ao turismo convencional.

A primeira pergunta realizada às operadoras (Para que levar pessoas (crianças, jovens, adultos, idosos) para visitar a natureza) foi utilizada como tema para a entrevista com os pesquisadores.

Este trabalho busca contribuir com o debate do Ecoturismo, pois há carência de material sobre o Ecoturismo nas óticas da cultura de consumo, sociedade do espetáculo, e modernidade líquida. Como contribuição social, este estudo visa gerar material para novas reflexões por parte de empresas, seus profissionais e ecoturistas. Pretendemos levar uma nova leitura do tema para além da academia, pois acreditamos que "todo conhecimento científico visa constituir-se em senso comum" (SANTOS, 
Hintze, H.C.

2003, p. 88-92). As reflexões propostas têm o intuito de colaborar com os atores envolvidos no pensamento e na ação do Ecoturismo no sentido de aproximá-los.

\section{A CONTEMPORANEIDADE E SEUS CONDICIONANTES.}

A contemporaneidade é chamada por vários nomes entre os sociólogos. É conhecida como modernidade tardia (HALL, 2000) e como modernidade líquida, conceito que tomamos do sociólogo polonês Zygmunt Bauman (BAUMAN, 2001). Podemos dizer que vivemos numa condição pós-moderna (HARVEY, 2003). Outros autores também abordam a questão. Adotaremos aqui as obras de Hall (2000), Bauman (2001) e Harvey (2003) como referência. Hobsbawm (1998) afirma que a partir do terceiro quarto do século $\mathrm{XX}$ os intelectuais passaram a tentar explicar os fenômenos que aconteciam num mundo que vivia uma revolução social. O prefixo pós- é inserido na tentativa de se explicar tal revolução. Analisaremos aqui, as questões da velocidade, fragmentações e superficialidade pós-modernas, pois tais características diferenciam a contemporaneidade de outros períodos históricos.

O mundo está mais rápido. Por um lado ouvimos que as vinte e quatro horas do dia não são suficientes para que façamos tudo que nos é (im)posto. Por outro, no dia-a-dia somos pais, mães, filhos, estudantes e professores, consumidores e eleitores. E nessa correria não aprofundamos as coisas afinal, não há muito tempo disponível. Mas, por que será que temos esta sensação? Vejamos então, algumas características que condicionam nosso tempo. Tais impressões têm origem no fenômeno chamado compressão espaço-tempo (BAUMAN, 2001; HARVEY, 2003) de fundamental importância para compreendermos este momento histórico. Doravante, denominaremos tal fenômeno por velocidade. Esta chega a seu quase-limite: vivemos no instantâneo e esta nova instantaneidade do tempo "conduz a cultura e a ética humanas a um território não-mapeado e inexplorado, onde a maioria dos hábitos aprendidos para lidar com os afazeres da vida perdeu sua utilidade e sentido" (BAUMAN, 2001, p. 149).

O século XX é o palco, no período após a $2^{\mathrm{a}}$ Guerra Mundial, para o rápido desenvolvimento dos transportes, dos sistemas de comunicação e, mais recentemente, da informática (HOBSBAWM, 1998; CASCINO, 2000a). Fatores que contribuíram para a aceleração da vida. Vivemos no tempo da aceleração da produção, pois é imperativo que se produza mais e mais, numa velocidade cada vez maior. Igualmente podemos perceber a questão da aceleração do consumo e da renovação das necessidades nos consumidores. Compreender o fenômeno dos ditames da moda nos parece elucidativo. Os mercados de massa da moda puderam fornecer uma forma de "acelerar o ritmo do consumo não somente em termos de roupas, ornamentos e decoração, mas também numa ampla gama de estilos de vida e atividade de recreação" (HARVEY, 2003, p. 258). É válido lembrar Robert Kurz, dizendo que aquilo que vira moda perde sua condição de crítica, pois "a moda é o oposto da crítica. Crítica radical não pode virar modismo sem perder a alma" (JAPPE, 1999, p. 5). Será o Ecoturismo uma moda? 
Vivemos em constante aceleração. Tempo do crescimento econômico, do sempre mais: mais escolas, informações, trabalho, mercadorias, viagens, turismo. A pósmodernidade é processo sem-fim de rupturas e fragmentações internas que são encontradas em várias dimensões, iniciadas no período da modernidade (HARVEY, 2003). Para compreendermos estas características é necessário que revisemos brevemente o que acontece neste período, denominado modernidade. Para Bauman (2001) este período é desde seu início um processo de liquefação dos sólidos prémodernos como as lealdades tradicionais, os direitos e obrigações dos costumes, do passado, da tradição, abrindo caminho para libertar a "empresa de negócios dos griIhões dos deveres para com a família e o lar e da densa trama de obrigações éticas [para] deixar restar somente o 'nexo dinheiro"' (BAUMAN, 2001, p. 7-22). Somente assim a economia pode tornar-se a base da vida social.

Foi na modernidade que se iniciou a fragmentação do conhecimento e da investigação científica no desenvolvimento das ciências, com a especialização do saber (e agora com a hiper-especialização do mesmo). O método científico assentou-se na redução da complexidade do mundo a qual a mente humana é incapaz de compreender completamente. Conhecer passou a significar dividir e classificar para depois poder determinar relações sistemáticas entre o que se separou; conhecer significa quantificar, pois aquilo que não é quantificável é cientificamente irrelevante (SANTOS, 2003).

Se de um lado, o desenvolvimento do cálculo na ciência moderna permitiu um grande avanço na tecnologia o qual se reflete no cotidiano, por meio do conforto doméstico, da velocidade dos meios de transporte, dos avanços da medicina; de outro, levou a um afastamento da questão qualitativa mediante a qual a humanidade encarava o mundo e o tempo. O princípio que se impõe é o da racionalização baseada "no cálculo, na possibilidade do cálculo" (LUKÁCS, 1989, p. 102). E, para tanto foi necessária sua especialização, produzindo / permitindo a fragmentação da produção.

Isso permitiu o desenvolvimento de um sistema mecânico praticamente independente do ser humano, tornando-o mero apêndice, um ser que contempla o que a máquina faz, pois a produção devidamente calculada deve seguir seu próprio ritmo e assim sendo cada vez mais a própria atividade do trabalhador "perde o seu caráter de atividade para se tornar numa atitude contemplativa" (LUKÁCS, 1989, p. 103). O consequente (re)posicionamento contemplativo deste sujeito frente à produção, à vida etc. teve consequências fundamentais para a sociedade do espetáculo (DEBORD, 2004). É nessa realidade fragmentada pela racionalização imposta pela mercadoria que pode surgir o 'trabalhador livre' para vender sua força de trabalho. Tal condição é a "expropriação violenta do tempo" (DEBORD, 2004, p. 108) do trabalhador. Tal processo extrapola as linhas de produção das fábricas, os limites dos muros das escolas, passando a "ser o destino geral de toda a sociedade" (LUKÁCS, 1989, p. 105), pois o trabalho assalariado agora é parte do cotidiano do cidadão e esta realidade é posta de tal maneira que "também aqui a personalidade se torna espectador impotente de tudo o que acontece à sua existência, parcela isolada e integrada num sistema estranho" (LUKÁCS, 1989, p. 104). Com a subjetividade do trabalhador fragmentada, tais 
condições tornam-se ideais para a instauração de um mercado que satisfizesse as necessidades dos consumidores através da produção de nova subjetividade.

Um período marcado pela velocidade e fragmentação tem como característica a superficialidade. Tudo tem significado vago, nada se afirma com certeza, com tendências a um relativismo que compromete a afirmação; um tempo no qual tudo é possível. É característica deste tempo o não aprofundamento de reflexões, ficando assim "difícil formular uma ideia contínua e, por conseguinte, uma ação contínua que possa ser plantada, que germine e que dê frutos" (CASCINO; HINTZE, no prelo).

A discussão sobre a contemporaneidade nos auxilia a situar e compreender os fenômenos que nela ocorrem. As demandas são rápidas e variadas, trocamos raízes e profundidade por "rizoma/superfície" (HARVEY, 2003, p. 48) e os processos de longa duração, como os educativos têm sua práxis comprometida. É muito difícil formular uma ideia de profundidade, ação contínua que provoque mudanças. É um tempo que favorece o 'farefismo', pois o mercado impôs-se e passou a determinar rumos e resultados, ou seja, produtos. Analisemos a cultura de consumo, cultura tipicamente pósmoderna (FEATHERSTONE, 1995, p. 122).

\section{A cultura de consumo}

Quando afirmamos que vivemos numa cultura de consumo, afirmamos que "o mundo das mercadorias e seus princípios de estruturação são centrais para a compreensão da sociedade contemporânea" (FEATHERSTONE, 1995, p. 121). Entendemos aqui cultura como a "emergência maior da sociedade humana" (MORIN, 2007, p.165). Cada cultura é composta por um capital cognitivo e técnico, entre eles as práticas e os saberes e um mitológico, composto por crenças, normas, etc. É a cultura dá forma e também normatiza. A cultura tem uma relação de reciprocidade com os indivíduos: ela os submete, mas por eles é constantemente influenciada. Cada sociedade é cercada por sua cultura. (MORIN, 2007, p.165). Para nosso estudo, a cultura de consumo tem três perspectivas fundamentais: (1) a expansão da produção das mercadorias e da acumulação de bens e locais de consumo; (2) utilização das mercadorias pelas pessoas para criar vínculos ou possibilitar distinções sociais; (3) os prazeres proporcionados pelo consumo e à existência de locais apropriados para a excitação física e os prazeres estéticos (FEATHERSTONE, 1995, p. 31). Ao tratarmos deste tema, abordamos mais que o simples gosto pelo consumo como algo banal, para o qual os consumidores dedicam boa parte do seu tempo, mas afirmamos que a "percepção e $o$ tratamento de praticamente todas as partes do ambiente social e das ações que o evocam e estruturam tende a ser orientados pela 'síndrome consumista' de predisposições cognitivas e avaliativas" (BAUMAN, 2007, p. 109). O autor aponta a remodelagem da Política ('P' maiúsculo) pela "síndrome consumista". (BAUMAN, 2007, p. 109).

A cultura de consumo desenvolve-se no período no qual o foco do capitalismo muda seu foco da produção para o consumo, levando assim o mercado para o centro 
da sociedade contemporânea e a mercadoria, para o centro de tal mercado (NOBRE, 2005). Situar e compreender o Ecoturismo no contexto da cultura de consumo é fundamental a este estudo, pois o Ecoturismo é o segmento do mercado turístico que mais cresceu, conforme apontado.

Na perspectiva da expansão da produção de mercadorias e locais de compra, a cultura de consumo transforma tudo em mercadoria, dando continuidade à dinâmica do capitalismo em gerar lucro. Tudo se torna consumível: tempo e experiência, natureza e consciência. A produção de mercadorias é constante; tudo se transforma em produto, venda, negócio, pacote. Para Bauman (2007) a cultura de consumo e seu mercado são a uma versão atualizada do sonho do Rei Midas afinal aquilo que o mercado toca, não importa o que seja, transforma-se em mercadoria de consumo - incluindo as coisas que "tentam escapar a esse domínio e até os meios e as formas utilizados em suas tentativas de escape" (BAUMAN, 2007, p. 118).

$\mathrm{Na}$ cultura de consumo, o produtor capitalista em sua ação tem cada vez mais o "'papel de alcoviteiro' entre os consumidores e seu sentido de necessidade, excitando neles apetites mórbidos, à espreita de cada uma de suas fraquezas - tudo isso para que possa exigir o numerário pelo seu serviço de amor" (HARVEY, 2003, p. 99).

Percebemos assim que o mercado tem uma fome insaciável e vai transformando tudo em mercadoria. Nada escapa a tal processo. Mas afinal, qual é a lógica da mercadoria? No vocabulário cotidiano, uma mercadoria é "qualquer produto suscetível de ser comprado ou vendido" (HOUAISS, 2001, p. 1897). Mas, na busca de respostas para as questões de nosso tempo abordadas nesta pesquisa devemos passar pela "solução do enigma da estrutura da mercadoria" (LUKÁCS, 1989, p. 97), pois tal questão assume posição essencial em nossa sociedade, afinal desde a modernidade a questão da mercadoria não é apenas um problema particular, mas é um problema estruturador da própria sociedade "em todas as suas manifestações vitais" (LUKÁCS, 1989, p. 97). O 'dinheiro e a troca no mercado põem um véu, 'mascaram' as relações sociais entre as coisas" (HARVEY, 2003, p. 98) fazendo-as parecer relações entre pessoas. Essa ilusória transparência torna opacas relações entre os consumidores e aqueles que produziram as mercadorias que são consumidas. Nas relações de compra e venda no mercado, os consumidores não reconhecem nenhum afeto por quaisquer sofrimentos ou dramas pessoais dos indivíduos que produziram tais mercadorias. É com a mercadoria (o dinheiro pago) que se dá a única relação.

Mario Beni, estudioso do turismo no Brasil, comenta que quanto ao "ar puro, o mar, as belezas naturais, é indubitável que estão hoje adquirindo, como nunca altos valores econômicos devido aos conglomerados urbanos sempre crescentes e às dificuldades de fruição, por todos, de um estilo de vida natural." (BENI, 2000, p. 38). O autor completa "sua apropriabilidade traduz-se na sua capacidade de utilização coletiva" (BENI, 2000, p. 38), ou seja, em seu consumo. Beni (2000) nos leva a refletir sobre a apropriação "irrestrita de praticamente todos os temas da sociedade pelo mercado" (SERRANO, 2000, p. 10) que Bauman (2007) compara ao sonho do Rei Midas. A cultura de consumo e suas implicações não são abordadas nas produções de autores 
de algumas correntes de análise do turismo.

O Ecoturismo nasceu como alternativa ao turismo convencional de exploração de massa. Uma nova forma de contato de seres humanos e natureza. Atualmente está mergulhado em disputas mercantis, como mercadoria. Questões até aqui abordadas são importantes se considerarmos a produção de subjetividade pelo sistema capitalista, ao tornar a natureza uma mercadoria e o ser humano em consumidor da natureza.

\section{A sociedade do espetáculo}

No vocabulário do cotidiano espetáculo é algo excepcionalmente interessante. Sua etimologia vem do latim "espectaculum: vista, aspecto, chamar a atenção pública, jogos públicos; derivado de espectare: olhar, observar atentamente, contemplar" (HOUAISS, 2001, p. 1229). Palavras que no sentido geral indicam uma atitude contemplativa, de passividade. Mas o significado de espetáculo neste trabalho, vai além das definições de dicionário. O Espetáculo é frequente, e propositalmente confundido com crítica aos meios de comunicação de massa (JAPPE, 1999). O espetáculo não é apenas uma crítica aos meios de comunicação de massa. Estes são apenas sua "manifestação superficial mais esmagadora, [e se isso] dá a impressão de invadir a sociedade como simples instrumentação, tal instrumentação nada tem de neutra: ela convém ao automovimento total da sociedade" (DEBORD, 2004, p. 20-21). Para além de uma crítica a tais meios, a teoria do Espetáculo pretende-se uma teoria crítica da sociedade contemporânea, apresentando a sociedade atual como aquela na qual mais se desenvolveu o sentido do fetichismo da mercadoria, sendo que este conceito se constitui como a "chave para compreender o mundo de hoje" (JAPPE, 1999, p. 15).

No primeiro estágio de desenvolvimento do Espetáculo houve uma degradação do sentido do 'ser' para o do 'ter'. Na fase atual a vida social está totalmente tomada pelos resultados acumulados da economia, "leva a um deslizamento generalizado do ter para o parecer, do qual todo 'ter' efetivo deve extrair seu prestígio imediato e sua função última" (DEBORD, 2004, p. 18). Esta transição entre ser, ter e parecer favorece a descartabilidade de tudo aquilo que é considerado sem mais valor.

No processo de empobrecimento da vida, por conta da fragmentação e separação, a sociedade perde todo seu aspecto unitário. O Espetáculo consiste na "recomposição, no plano da imagem, dos aspectos separados", (JAPPE, 1999, p. 20), afinal ele é a "perda da unidade do mundo" (DEBORD, 2004, p. 23). O capitalismo promove a decomposição da vida cotidiana, na qual a racionalidade da mercadoria (das imagens), perpassa todas as relações humanas, pois "o espetáculo não é um conjunto de imagens, mas uma relação social entre pessoas mediada por imagens" (DEBORD, 2004, p. 14). O cidadão/consumidor é espectador passivo, pois "a contemplação passiva de imagens, que ademais foram escolhidas por outros, substitui o vivido e a determinação dos acontecimentos pelo próprio indivíduo" (JAPPE, 
1999, p. 19).

Assim como na religião, o espetáculo obedece ao mesmo mecanismo que projeta 'no céu' a finalidade última da vida 'na terra'. Afinal, no espetáculo assim como na religião "cada momento da vida, cada ideia e cada gesto só encontram seu sentido fora de si mesmo" (JAPPE, 1999, p. 22). É o desenvolvimento de uma ideia, que descontrola (autonomizada), domina seu criador. Os deuses criados pela humanidade a dominaram e o espetáculo nada mais é que "a reconstrução material da ilusão religiosa" (DEBORD, 2004, p. 19), produzindo assim em favor do objeto contemplado, a alienação do espectador, então "quanto mais ele contempla, menos vive; quanto mais aceita reconhecer-se nas imagens dominantes da necessidade, menos compreende sua própria existência e seu próprio desejo" (DEBORD, 2004, p. 24).

A economia não atende mais aos desejos humanos, visa apenas sua própria reprodução num processo sem fim e com isso torna-se um processo alienante (JAPPE, 1999), pois "a economia transforma o mundo, mas o transforma apenas em mundo da mercadoria" (DEBORD, 2004, p. 30), submetendo a si toda vida humana. $O$ espetáculo é o "dinheiro que apenas se olha, porque nele a totalidade do uso se troca contra a totalidade da representação abstrata" (DEBORD, 2004, p. 34). A necessidade contínua de busca de lucro, de aumento da natureza do valor subordina toda a vida humana e despreza o trabalho realizado para que se atinja este fim. Visa apenas a produzir, no fim de seu ciclo, uma quantidade de valor, sob a forma de dinheiro maior do que possuía no início (JAPPE, 1999, p. 32).

Estas relações não estão presentes apenas na questão do trabalho, elas estão na vida em sua totalidade. Se durante a fase inicial do capitalismo, o proletário deveria apenas cumprir o papel de operário, quando um determinado nível de produção é atingido, ele é convocado a participar do sistema econômico de outras maneiras e

subitamente lavado do absoluto desprezo com que é tratado, em todas as formas de organização e controle da produção, ele continua a existir fora dessa produção, aparentemente tratado como adulto, com uma amabilidade forçada, sob o disfarce de consumidor. [...] o humanismo da mercadoria se encarrega dos "lazeres e da humanidade" do trabalhador (DEBORD, 2004, p. 31).

A economia invade completamente a vida social, por meio do consumo, dos lazeres etc., pois "não só o trabalho, mas também as outras atividades humanas, o que se chama de tempo livre, são organizados de modo a justificar e a perpetuar o modo de produção vigente" (JAPPE, 1999, p. 25). O lazer dirigido segue o mesmo ritmo do trabalho alienado. A atitude meramente contemplativa, antes característica do trabalho agora se estende por todo o conjunto de atividades sociais, pois o espetáculo é a "afirmação onipresente da escolha já feita na produção, e o consumo que decorre desta escolha" (DEBORD, 2004, p. 14-15), colocando o lazer assim em condição de atividade alienada, pois obedece igualmente à lógica da continuidade do capital. Con- 
sideramos tal mecanismo como compensatório (lazer para compensar o trabalho) e como válvula de escape, um lazer alienante no qual se extravasam as pressões de um trabalho alienado. Isso implica na invasão de toda a vida social. Assim, "tudo o que falta à vida se encontra nesse conjunto de representações independentes que é o espetáculo" (JAPPE, 1999, p.20). Os indivíduos estão socialmente isolados e só encontram "sua unidade no espetáculo" (JAPPE, 1999, p. 20). Porém, "o espetáculo reúne o separado, mas o reúne como separado" (DEBORD, 2004, p. 23) reforçando assim sua própria condição. Quanto mais o indivíduo sente-se separado, mais precisa do Espetáculo, como forma de pseudo-integração, quanto mais precisa do Espetáculo, mais se separa. Atualmente a massa de oprimidos já não é composta apenas pelos trabalhadores de indústria, mas sim por todos os assalariados, pequenos produtores etc (FREITAG, 2004). É, enfim, a "proletarização do mundo" (DEBORD, 2004, p. 22).

A substituição do tempo 'qualitativo' por um 'quantitativo' na racionalidade da produção torna-o tempo-mercadoria, uma acumulação infinita de intervalos equivalentes. Desvalorizado representa a "inversão completa do tempo como 'campo de desenvolvimento humano' [...] um tempo pseudocíclico [...enfim] tempo espetacular" (DEBORD, 2004, p. 103-105). O tempo pseudo-cíclico não está baseado em traços naturais do tempo, ele cria "novas combinações homólogas: o dia e a noite, o trabalho e o descanso semanais, e a volta dos períodos de férias" (DEBORD, 2004, p. 104)

O tempo de lazer se torna uma imagem social para o consumo. É uma mercadoria espetacular dominada por momentos de lazer e de férias que são alvo de grande desejo. Esta mercadoria deve ser oferecida como um "momento da vida real, cujo retorno cíclico deve ser aguardado" (DEBORD, 2004, p. 106). No entanto, em tais momentos concedidos à vida ainda é o espetáculo que se "mostra e se reproduz, atingindo um grau mais intenso. O que foi representado como a vida real revela-se apenas como a vida mais realmente espetacular" (DEBORD, 2004, p. 106). O consumo tem como missão preencher o tempo livre dos trabalhadores e passa a ser a resposta para a felicidade. A mídia oferece diz que "a felicidade não precisa ser adiada para o futuro, por já estar concretizada no presente" (FREITAG, 2004, p. 72-73).

O Espetáculo não é apenas dinheiro ou bens materiais, mas "toda a extensão da sociedade é seu retrato" (DEBORD, 2004, p. 34), pois tudo se tornou mercadoria. É o "vínculo abstrato que a troca institui entre os homens" (JAPPE, 1999, p. 36). Momento em que a mercadoria toma uma dimensão tão concentrada que se torna imagem, como no irônico aforismo que Debord faz em alusão a um dos pensamentos de Marx: "toda a vida das sociedades em que reinam as condições modernas de produção apresenta-se como uma imensa acumulação de espetáculos" (DEBORD, 2004, p.13). A questão da imagem é fundamental no entendimento da sociedade do espetáculo, pois "quando o mundo real se transforma em simples imagens, as simples imagens tornam-se seres reais e motivações eficientes de um comportamento hipnótico" (DEBORD, 2004, p. 18). O espetáculo utiliza-se da visão como sentido privilegiado 
do ser humano, mas é um mundo que já não se pode ver diretamente (DEBORD, 2004, p. 18). Isso ajudará a situar o Ecoturismo no contexto das atividades espetaculares, que se dão no consumo de imagens, sejam da natureza, de comunidades receptoras ou de outras apropriações. O turismo - por parentesco o Ecoturismo - como circulação humana em busca de um consumo que se resume num lazer de idas e vindas para ver o que se tornou banal no "seio das mesmas redundâncias de imagens $e$ comportamentos" (GUATTARI, 2001, p. 8) temos que o planejamento econômico da frequência dos diferentes lugares garante sua equivalência, pois "a mesma modernização que retirou da viagem o tempo, Ihe retirou também a realidade do espaço" (DEBORD, 2004, p. 112).

\section{ECOTURISMO NA CULTURA DE CONSUMO}

\section{O turismo convencional na tendência hegemônica}

O turismo é um fenômeno moderno. A estruturação da modernidade - conversão do tempo orgânico em tempo de produção; surgimento do tempo pseudocíclico e compensação desta perda qualitativa da relação com o tempo pela prática da evasão; as condições de vida urbana; o ritmo das cidades; as relações de trabalho e os direitos trabalhistas - favoreceu o início das viagens turísticas com o objetivo busca de prazer e emoção, com intuito de desenvolvimento pessoal e da apreciação estética (THOMAS, 1989; SERRANO, 2000; SALGUEIRO, 2002). O turismo como é conhecido atualmente encontra um importante ponto estruturador nas viagens de jovens da aristocracia ao final do século XVII. Ao final do século XVIII que o Grand Tour dos ingleses passa a se estruturar e se disseminar entre a classe média urbana. Tal desenvolvimento estimulou a institucionalização e a oferta de serviços como os de "hospedagem, e o surgimento dos guias - seja como pessoas, seja na forma de livros - que contribuem para a disseminação de rotinas, códigos e signos das viagens" (SERRANO, 2000, p. 38).

A OMT define o turismo como "atividades de pessoas que viajam para lugares afastados de seu ambiente usual, ou que neles permaneçam por menos de um ano consecutivo, a lazer, a negócios ou por outros motivos" (OMT, 2003, p. 20). As motivações turísticas (ANDRADE, 1997, p. 85-97) são diversas: desejo de evasão causado pela "artificialização da vida" (OURIQUES, 2005, p. 40), espírito de aventura, aquisição de status, necessidade de tranquilidade, motivação cultural e comercial etc.

Os atrativos turísticos referem-se a "todo lugar, objeto ou acontecimento de interesse turístico que motiva o deslocamento de grupos humanos para conhecêlos" (BENI, 2000, p. 330). Os bens turísticos podem ser naturais, histórico-culturais, como manifestações e usos tradicionais e populares, realizações técnicas e científicas contemporâneas ou acontecimentos programados, enfim "todos os elementos subjetivos e objetivos ao nosso dispor, dotados de apropriabilidade, passíveis de receber um valor econômico, ou seja, um preço" (BENI, 2000, p. 38). 
O produto turismo é fruto da combinação do uso de bens tangíveis como, aviões, hotéis, carros; de serviços prestados por profissionais, como guias de turismo, agentes de viagens etc.; utilização dos atrativos turísticos, que podem ser qualquer coisa: o Cristo Redentor ou o Parque Nacional do Itatiaia, uma árvore centenária, uma cachoeira etc; estruturas existentes como estradas, portos e aeroportos; outras instâncias como a localidade, o território, a paisagem, os habitantes do local, seus costumes, cultura, tradições; comercializa o lugar sob a forma metafórica do pacote.

Podemos perceber na análise de Beni (2000) a apropriação do capital sobre os lugares, objetos ou acontecimentos e na sua conversão em produtos turísticos. Qualquer que seja o interesse das pessoas, o capital pode converter em atrações turísticas para visitação. O mercado do turismo empacota os "lugares e seus atrativos e serviços, além da subjetividade, utilizando-a juntamente com o ambiente, como matéria-prima para a produção de mais uma mercadoria" (SERRANO, 2001, p. 206). Segundo tal tendência, o turismo é em sua essência uma atividade econômica que movimenta mais de cinquenta setores produtivos de bens e serviços. (ROSE, 2002, p. 2).

O produto turístico é uma mescla das etapas da exploração do capital, unindo bens físicos e serviços num mesmo pacote: bens materiais, imóveis, duráveis ou perecíveis, de consumo, de capital, básicos, complementares e interdependentes, naturais ou artificiais; por serviços turísticos: receptivos, de alimentação, de transporte, públicos, de recreação e entretenimento. (BENI, 2000, p. 38). Na prestação de serviços, o tempo de vida dos 'produtos' é bem menor que dos bens físicos como automóveis ou máquinas de lavar etc. Isso faz com que os capitalistas se voltem para o fornecimento de serviços efêmeros em termos de consumo. (HARVEY, 2003, p. 258)

Como atividade econômica é "resultado de inúmeras atividades de transformação e produção" (ANSARAH, 2001, p. 24). A maioria das abordagens de tais autores vê o turismo como atividade econômica, mesmo quando discursam sobre comunidades, localidades, culturas etc., isso se dá do ponto de vista econômico, como recurso. Uma atividade econômica que possibilita o desenvolvimento de localidades ao permitir a geração de rendimentos que são reinvestidos "na estruturação dos elementos da oferta e/ou distribuídas entre os demais setores produtivos da localidade receptora, favorecendo sobremaneira toda a comunidade" (ROSE, 2002, p. 2).

O produto turístico é um fenômeno do tempo livre, fruto de inúmeras conquistas trabalhistas, por exemplo, a redução do tempo de trabalho, férias remuneradas etc. Os descansos diários, semanais, anuais e aposentadoria permitiram às pessoas aproveitar este período para seu lazer e é claro, para o consumo. O lazer encontra no turismo uma fonte de fruição. (SERRANO, 2000; BENI, 2000; ANSARAH, 2001).

De acordo com a bibliografia consultada, sob uma visão economicista, o turismo pode causar impactos, tanto positivos como negativos, sobre o ambiente natural ou socialmente produzido. A prática do turismo impacta seu próprio substrato como, por exemplo, solos e vegetação; recursos minerais e fósseis; a água e recursos hídricos; formações rochosas; vida selvagem (fauna nativa); paisagem (PIRES, 2005). 
Considerando ainda o impacto do turismo na cultura e sociedade, podemos elencar alguns itens, pois para cada efeito positivo do turismo é possível associar-se um efeito colateral. A leitura da tendência hegemônica defende a geração de emprego, renda e estímulo ao desenvolvimento econômico em vários níveis (local, regional, estadual, nacional) pelo turismo (BENI, 2000; ANSARAH, 2001), no entanto, o que ocorre é a substituição de ocupações tradicionais por subempregos, nos quais as pessoas da localidade passam a exercer funções em outras atividades como caseiros, ou empregados da construção civil, de órgãos públicos ou serviços relacionados ao comércio (LUCHIARI, 2001, p. 67). Se por um lado o intercâmbio de ideias, costumes e estilos de vida entre visitantes e visitados pode ser proveitoso durante uma atividade ecoturística, por outro essa experiência pode converter-se em perda de valores tradicionais em consequência da homogeneização das culturas (SERRANO, 2001).

Com a apresentação de impactos e por conta da exploração do turismo com proporções de indústria de massa, agressiva aos lugares explorados, este passou a receber críticas de alguns autores. Como alternativa surgem formas de se explorar o turismo, com novos discursos sobre desenvolvimento. É necessário pensar uma maneira de se praticar o turismo de modo 'sustentável', que é aquele que "atende às necessidades dos turistas de hoje e das regiões receptoras, ao mesmo tempo em que protege e amplia as oportunidades para o futuro" (OMT, 2003, p. 24). Também é visto como possibilidade de condução ao gerenciamento de todos os recursos, "de tal forma que as necessidades econômicas, sociais e estéticas possam ser satisfeitas sem desprezar a manutenção da integridade cultural, dos processos ecológicos essenciais, da diversidade biológica e dos sistemas que garantem a vida" (OMT, 2003, p. 24)

O conceito de turismo sustentável engloba três dimensões. A dimensão ambiental: o meio ambiente, tanto natural quanto construído; a dimensão econômica: a vida econômica de comunidades e empresas; a dimensão social: os aspectos sociais do turismo, em termos de seus impactos sobre culturas locais e turistas, e o modo como são tratados os que trabalham no turismo (SWARBOOKE, 2000a, p. 73-109). A prática do turismo - em seu discurso e conceito - passa da fase de exploração intensiva para a fase sustentável e pode ser explorado como vetor de tal desenvolvimento.

A segmentação de mercado do turismo identifica comportamentos homogêneos dos clientes quanto a seus gostos e preferências para obter informações sobre destinos, tipos de transportes, composição demográfica dos turistas, sua situação social e estilo de vida, sendo o motivo da viagem a principal forma de se segmentar o mercado (BENI, 2000; ANSARAH, 2001). Segmentar o mercado tenta resolver os problemas do turismo de massas e apresentar uma pseudodiferenciação entre os consumidores do produto turístico. Aparentemente cada segmento de clientes interessa-se por um tipo específico de turismo. Podemos perceber que cada interesse particular é utilizado para um objetivo comum: a busca pelo lucro por meio da conversão da experiência turística em mercadoria na cultura de consumo. 
Hintze, H.C.

\section{Ecoturismo como segmento do mercado turístico}

O Ecoturismo é considerado o "segmento da atividade turística" (BRASIL, 1994, p. 19) com maior crescimento pelo Ministério do Turismo do Brasil nas Diretrizes para a Política Nacional de Ecoturismo (DPNE). Para o mercado turístico, é um de seus principais produtos em forte expansão (BRASIL, 1994, p. 9-12). Tem como diferenciais, o atendimento a pequenos grupos de até 25 pessoas; utilização de meios de hospedagem com menos de 100 leitos; operação por empresas de pequeno a médio porte, concentrando-se na condução e na acomodação de pequenos grupos para oferecer atendimento mais personalizado com o uso de materiais interpretativos e guias especializados, além da preocupação com a capacitação de guias, operadores e fornecedores dos serviços requeridos pela atividade (PIRES, 2005). O Ecoturismo é uma área especializada que inclui viagens às áreas naturais ou com presença humana baixa, em que "o ecoturista envolvido na experiência externa busca uma motivação explicita de satisfazer sua necessidade por educação e consciência ambiental, social e/ou cultural por meio de visita à área e vivência nela" (PIRES, 2005, p. 484).

Em Pires (2002), não se compreende 'sol e praia' e 'rural' como atividades desenvolvidas na natureza, embora estas se deem em locais compreendidos por ambientes naturais - praia e do rural, em fazendas, levando o imaginário que natureza não os compreende, ficando restrito a locais como a Mata Atlântica, Pantanal ou Amazônia.

\section{Ecoturismo: origem, contexto e significado}

Na década de 1970, o turismo estava no auge de sua exploração de massa e representava o paradigma social dominante - culto ao progresso e à prosperidade do crescimento econômico, sobrepondo-se às questões ambientais, desconhecendo limites para o crescimento (PIRES, 2002, p. 34).

As origens históricas do Ecoturismo estão no caldo cultural que ao final da década de 1960 e inícios dos anos de 1970 agitava o mundo com questões ecológicas, pacifistas, feministas, dos negros no movimento Black Power, o movimento Hippie, o Flower Power, entre outros. Movimentos de minorias que em sentido amplo podem ser considerados ambientalistas, com princípios questionadores da sociedade capitalista - seu desenvolvimento, padrões e limites - da qual uma das características mais marcantes é o consumismo. A palavra turismo recebeu o prefixo eco- que etimologicamente vem do grego "oikos, que significa lar ou habitat. O meio ambiente que nós, os humanos, habitamos é, em sua máxima essência, o nosso lar, a nossa morada, o nosso sustento" (WEARING; NEIL, 2001, p. xvii). A origem do Ecoturismo tem suas raízes numa filosofia de vida baseada na herança filosófica adotada por movimentos ambientalistas. O primeiro a usar a palavra ecoturismo foi Hector Ceballos-Lascuráin no ano de 1983 (PIRES, 2002).

A palavra 'alternativo' tem como radical alter- que significa "um outro, outrem; 
outro, diferente, oposto, contrário" (HOUAISS, 2001, p. 168) da raiz al- que significa outro. É originário do latim e diz muito na busca pelo sentido desta palavra, pois dizer que algo é alternativo é dizer que "oferece possibilidade de escolha, de opção [e que é] capaz de funcionar como outra resposta, remédio, saída" (HOUAISS, 2001, p. 169). Compreender a palavra 'alternativo' é uma primeira aproximação ao comportamento do Ecoturismo em relação ao turismo convencional. Alternativo é aquilo que não busca ser hegemônico, que se contenta em viver à margem.

O Ecoturismo foi originariamente concebido como uma forma de turismo de baixo impacto sobre os locais e comunidades nas quais se desenvolve, como 'alternativa' ao turismo convencional de massas, que causa os mais diversos impactos ambientais e sociais. Ele participa do turismo alternativo, ou seja, deve tentar minimizar o impacto ambiental e sociocultural negativo dos turistas, "promovendo abordagens radicalmente diferentes em relação ao turismo convencional". (WEARING; NEIL, 2001, p. 2).

Este outro turismo pode ser descrito como de baixo impacto, que visa à interpretação do ambiente visitado e é promovido de maneira discreta, desejando a conservação de tal local, pois este é seu próprio substrato (SERRANO, 2000).

Segundo as DPNE, o Ecoturismo é

um segmento da atividade turística que utiliza de forma sustentável o patrimônio natural e cultural, incentiva sua conservação e busca a formação de uma consciência ambientalista através da interpretação do ambiente, promovendo o bem-estar das populações envolvidas. (BRASIL, 1994, p. 19)

Para o Poder Público o Ecoturismo é parte do mercado turístico e, sua exploração está sujeita às regras de tal mercado; deve utilizar-se de forma sustentável o patrimônio natural e cultural, inserindo em seu discurso a questão da sustentabilidade; deve incentivar a conservação de tal patrimônio natural e cultural, pois é seu substrato e é também uma forma de desenvolvimento econômico; deve buscar a formação de uma consciência ambientalista afirmando que esta se dá pela interpretação do ambiente, ou seja, nas atividades ecoturísticas é necessário que se permitam aos envolvidos desenvolver tal consciência; por fim, promover o bem estar das populações envolvidas, não se restringindo apenas à questão econômica.

Segundo os teóricos estudados, as atividades que buscam o status de Ecoturismo, além de serem desenvolvidas em ambientes naturais, devem considerar a difusão de uma "consciência ecológica pelo advento da Educação Ambiental" (PIRES, 2002, p. 159) em suas práticas de mercado. Sendo assim, Pires (2002) em seu estudo sobre o Ecoturismo considera que este apresenta a introdução do componente educacional (PIRES, 2002, p. 156) como diferencial às outras formas de exploração turística. O contato direto e 
de primeira mão com os ambientes naturais e com as manifestações ou aspectos culturais presentes no seu encontro possibilita aos turistas e visitantes uma oportunidade preciosa para desenvolver a percepção ambiental e assimilar conhecimentos que influenciarão decididamente na formação de uma consciência ecológica e cultural capaz de determinar posturas e atitudes diante do ambiente e da sociedade (PIRES, 2005, p. 485)

No caso do Brasil, o Ecoturismo é visto como uma possibilidade para a Educação Ambiental. Para que uma atividade turística receba o prefixo eco-, deve considerar três aspectos básicos: os critérios de sustentabilidade ambiental, social, cultural e econômica; "o aspecto educativo [...] que relaciona-se com a disseminação da educação, sobretudo a ambiental, entre todos os envolvidos no andamento da atividade" (PIRES, 2002, p.158) e participação das comunidades locais

O Programa das Nações Unidas para o Meio Ambiente (UNEP) reconhece que é necessário "incluir a interpretação ambiental, a experiência da aprendizagem no ambiente" (PIRES, 2002, p.160) como requisito para um padrão de sustentabilidade. $O$ Ecoturismo deve privilegiar as experiências participativas e esclarecedoras que incentivam uma educação de todas as partes, comunidades locais e o governo, as organizações não-governamentais, a indústria e os turistas, antes e durante como depois da experiência da viagem. Deve incentivar nos envolvidos, o reconhecimento de valores intrínsecos dos recursos naturais e culturais. (SWARBROOKE, 2000b, p. 65)

Ainda em referência à questão do caráter alternativo do Ecoturismo em relação ao turismo, espera-se do ecoturista um comportamento diferenciado daquele do turista convencional. O primeiro deve possuir uma ética ambiental e boa vontade de não degradar o recurso visitado; deve ter foco na motivação intrínseca e não extrínseca; ter orientação biocêntrica em vez de antropocêntrica e a intenção de beneficiar a vida selvagem e o ambiente natural; além de procurar uma experiência direta com tal ambiente. Quanto ao quesito educacional, espera-se que o ecoturista procure e tenha expectativa de educação e apreciação; além de alta dimensão cognitiva e afetiva. Comparando os turistas convencionais aos ecoturistas, os primeiros em férias têm a tendência de apresentar atitudes menos conscientes para como o ambiente, ao passo que os ecoturistas tentam minimizar os impactos de sua visita no local de destino.

Quanto às estruturas de recepção dos lugares visitados, o ecoturista procura adaptar-se ao meio ambiente, e o turista convencional adapta o meio ambiente a seu comportamento cotidiano. O fato que une turistas convencionais e ecoturistas é que ambos se movem de um lugar para o outro buscando novas experiências. (WEARING; NEIL, 2001, p. 198-209), para vivenciá-las, para consumi-las.

Numa rápida comparação entre o turismo de aventura e o Ecoturismo podemos conferir que o primeiro busca ambientes remotos para sua prática, há maior incerteza quanto aos resultados dos programas, é buscada uma minimização dos impactos ne- 
gativos e há tanto resultados como riscos inesperados; no segundo há a necessidade das práticas de Educação Ambiental, há um maior interesse por cultura, paisagens e pela interpretação do ambiente, é desejável um número reduzido de clientes e igualmente há a preocupação com a minimização dos impactos (RAMOS, 2005, p. 475).

A Educação Ambiental participa conceitualmente do Ecoturismo, mas não do turismo de aventura. Há uma tênue linha difícil de ser apreendida e que gera bastante confusão entre os conceitos. A prática da Educação Ambiental é o grande diferencial do Ecoturismo para outras formas de turismo.

\section{EDUCAÇÃO AMBIENTAL}

A educação em seu amplo significado tem como missão dedicar-se à identificação da origem de erros, ilusões e cegueiras, e com isso, armar cada um para o combate vital para a lucidez; realizar o exame e o estudo da complexidade humana; e ensinar a ética da compreensão planetária, através de uma reforma em sua mentalidade (MORIN, 2000). Por isso, não deve limitar-se aos bancos escolares de um sistema formal de ensino. Tal educação deve ser explorada de várias outras maneiras. Nos referimos à Educação Ambiental. A Política Nacional de Educação Ambiental - Lei 9795 de 27/04/99 foi elaborada pelo Programa Nacional de Educação Ambiental. Ela aborda a Educação Ambiental como parte do processo educativo da nação nos âmbitos formal e não-formal. De acordo com tal lei (Capitulo II - Seção III - Artigo 13 - Inciso VII), entende-se por Educação Ambiental não-formal

as ações e práticas educativas voltadas à sensibilização da coletividade sobre as questões ambientais e à sua organização e participação na defesa da qualidade do meio ambiente. Parágrafo único: O poder público, em níveis federal, estadual e municipal, incentivará: VII: o Ecoturismo (BRASIL, 1999, p. 6).

A pesquisa de campo nos mostrou que as operadoras entendem que educação é tomada pelo viés formal. A partir das afirmações das operadoras parece que há uma crença de que a educação não deve se misturar com o turismo, momento supremo de lazer dos clientes pagantes. Acreditamos que o contato com a natureza pode ser uma possibilidade de educação fora do âmbito escolar e, portanto, não submetido às mesmas metodologias. É necessário afirmar que o potencial das visitas a um ambiente natural pode promover possibilidades educativas diferenciadas do ambiente escolar. Todavia, tais atividades devem ser realizadas considerando a Educação Ambiental de maneira ampla "não se restringindo à reprodução das estratégias educacionais tradicionais, que enquadram o conhecimento e inibem as experiências e as expressões criativas" (MENDONÇA; NEIMAN, 2003, p. 166). A Educação Ambiental deve contemplar todos os aspectos do ambiente abrangendo "os aspectos políticos, sociais, econômicos, científicos, tecnológicos, culturais, ecológicos e éticos" (DIAS, 
2003, p.82)

Em 1987, a publicação do texto Nosso Futuro Comum como resultado de um trabalho iniciado em 1983 pela $1^{\mathrm{a}}$ Ministra da Noruega, Gro Brundtland e equipe, tornou-se referência para os próximos passos. Concluiu-se que a Educação Ambiental deveria preocupar-se com a conscientização, com a transmissão de informações, e com o "desenvolvimento de hábitos e habilidades, promoção de valores, estabelecimento de critérios e padrões, e orientações para a resolução de problemas e tomadas de decisões. Portanto, deveria objetivar modificações comportamentais nos campos cognitivos e afetivos" (DIAS, 2003, p. 140).

Propor modificações comportamentais nos campos cognitivos e - especialmente - afetivos foi um importante passo (e diretamente relacionado à temática deste estudo) no sentido da subjetividade da Educação, na sensibilização das pessoas para a mudança de atitude, hábitos e valores por outras vias que não apenas a informação.

Um importante documento na história da Educação Ambiental é o Tratado de Educação Ambiental para Sociedades Sustentáveis e Responsabilidade Global (Tratado). O princípio número 1 do Tratado afirma que "A educação é um direito de todos, somos todos aprendizes e educadores" (FÓRUM, 1992, p. 1). Tal princípio fala sobre a educação e a relação entre seus sujeitos, que apesar das diferenças que os conotam, não se reduzem à condição de objeto, um do outro, pois "quem ensina aprende ao ensinar e quem aprende ensina ao aprender" (FREIRE, 2002, p. 25). É necessário reconhecer que todos os envolvidos no processo educativo estão em condições de aprender e de ensinar. O princípio 2 afirma que a Educação Ambiental deve ter como base o "pensamento crítico e inovador, em qualquer tempo ou lugar, em seus modos formal, não-formal e informal, promovendo a transformação e a construção da sociedade" (FÓRUM, 1992, p. 1-2). Enquanto o princípio número 4 diz que a Educação Ambiental "não é neutra, mas ideológica. É um ato político, baseado em valores para a transformação social". (FÓRUM, 1992, p. 1-2).

A educação libertadora de Freire está a serviço da construção deste espírito crítico, inovador e autônomo. Há nestes princípios a influência e importância da pedagogia freireana para a Educação Ambiental. Freire não escreveu uma linha sequer sobre a Educação Ambiental, mas sua pedagogia foi fundamental para a elaboração do Tratado, pois se pode perceber a presença de suas ideias em vários momentos do texto. Sua obra é importante fundamento para tal educação, se esta se pretende crítica. $\mathrm{O}$ ato educativo deve inscrever-se num movimento de leitura do mundo e de sua problematização e deve visar à criação de possibilidades da construção de um conhecimento com autonomia. A tarefa da educação é "indagar ao mundo, questioná-lo, pensar sua mudança, sugerir ações e refletir sobre os resultados desta" (CASCINO; HINTZE, no prelo). Freire denuncia a educação bancária, na qual "o 'saber' é uma doação dos que se julgam sábios aos que julgam nada saber. Doação que se funda numa das manifestações instrumentais da ideologia da opressão" (FREIRE, 2001, p. 58). Encontramos em sua pedagogia, os ensinamentos para uma educação que visa à transformação social, pois sabemos que "ensinar não é transferir conhecimento, 
mas criar as possibilidades para a sua produção ou a sua construção" (FREIRE, 2002, p. 25). Esta questão nos interessa por sua relação direta com a Educação Ambiental não-formal do Ecoturismo, pois durante as visitas a ambientes naturais, o condutor de grupos assume o papel de educador, conduzindo os ecoturistas e tendo a oportunidade de promover situações que se convertam em experiências educativas. $\mathrm{Na}$ Educação Ambiental, a produção do conhecimento deve dar-se através da cooperação, da troca e não de relações professorais de imposição. Deve preocupar-se com o contexto em que se desenvolve com a cultura, pois "não se faz educação dentro da cabeça de ninguém; se faz educação no contexto histórico, no contexto cultural. É por isso também que ela não pode ser neutra; não há, nunca houve, nem vai haver neutralidade educacional" (OVALLES; VIEZZER, 1995, p. 14).

O princípio número 5 diz que "a Educação Ambiental deve envolver uma perspectiva holística, enfocando a relação entre o ser humano, a natureza e o universo, de forma interdisciplinar" (FÓRUM, 1992, p. 1-2), afinal o ambiente deve ser considerado em sua complexidade de relações e não de forma fragmentada. $E$ no princípio número 15 a Educação Ambiental deve integrar conhecimentos, aptidões, valores, atitudes e ações e "deve converter cada oportunidade em experiências educativas de sociedades sustentáveis" (FÓRUM, 1992, p. 1-2). O princípio aponta para a conversão das experiências do Ecoturismo em experiências educativas, assim como faz a lei de Educação Ambiental ao indicá-lo como estratégia da Educação Ambiental não-formal.

No princípio número 16 a Educação Ambiental deve ajudar a desenvolver "uma consciência ética sobre todas as formas de vida com as quais compartilhamos este planeta, respeitar seus ciclos vitais e impor limites à exploração dessas formas de vida pelos seres humanos" (FÓRUM, 1992, p. 1-2) aprofundando assim o debate sobre a valoração das coisas e a análise crítica a respeito da condição humana em relação ao mundo. O contato entre os seres humanos e a natureza pode propiciar tal educação.

A diretriz número 5 aponta para a necessidade do "desenvolvimento de conhecimentos, metodologias e práticas de Educação Ambiental em todos os espaços de educação formal, informal e não-formal e para todas as faixas etárias" (FÓRUM, 1992, p. 3). Para isso, como aponta a diretriz número 6 é necessário que se possa "promover e apoiar instâncias de capacitação de recursos humanos para o gerenciamento do ambiente, como parte do exercício da cidadania local e planetária" (FÓRUM, 1992, p. 3). A diretriz número 07 fala sobre a necessidade de "estimular posturas individuais e coletivas, bem como políticas institucionais, que revisem permanentemente nossa coerência entre discurso e práticas, os valores de nossa cultura, nossas tradições e nossa história" (FÓRUM, 1992, p. 3). A atenção à relação entre discurso e prática também encontra eco na obra de Paulo Freire.

O Ecoturismo no Brasil em sua definição pelo Poder Público deve desenvolver uma "consciência ambientalista" (BRASIL, 1994, p. 19) em seus praticantes. Isso encontra respaldo no Tratado em sua diretriz número 21, para a qual é preciso "assegurar que os grupos de ecologistas popularizem suas atividades e que as comu- 
nidades incorporem em seu cotidiano a questão ecológica" (FÓRUM, 1992, p. 3). Diferentemente do processo educativo formal, o Ecoturismo como possibilidade para a prática da Educação Ambiental não-formal não pode ser considerado um processo, no sentido de sua continuidade em longo prazo, pois suas atividades são pontuais.

A diretriz 16 traz uma das mais difíceis missões para o Tratado que é a de "promover a compreensão das causas dos hábitos consumistas e agir para a transformação dos sistemas que os sustentam, assim como para a transformação de nossas próprias práticas" (FÓRUM, 1992, p. 3).

Dentre os grupos a serem envolvidos em sua dinâmica estão os empresários que tenham compromisso em atuar dentro de uma "lógica de recuperação e conservação do meio ambiente e da melhoria da qualidade de vida humana" (FÓRUM, 1992, p. 5). Também devem envolver-se, todos os profissionais da educação que estejam interessados em "implantar e implementar programas voltados à questão ambiental tanto nas redes formais de ensino como em outros espaços educacionais" (FÓRUM, 1992, p. 5). Pensamos aqui, nos empresários do Ecoturismo.

\section{As contribuições de Henry David Thoreau para a Educação Ambiental}

A Educação Ambiental deve integrar conhecimentos e "impor limites à exploração às formas de vida" (FÓRUM, 1992, p. 1-3) por parte dos humanos para empreender a transformação humana e social, além da preservação ecológica. A educação deverá questionar o sistema de exploração vigente. Acreditamos que o pensador americano Thoreau tem algo a dizer sobre isso, pois sua obra e vida tornaram-se um grande símbolo de resistência e fonte de inspiração para a maioria dos movimentos ambientalistas. Embora o autor não tenha escrito nada especificamente sobre o tema Educação Ambiental, nem tampouco Ecoturismo. Acreditamos, todavia, que é possível aproveitar seus conceitos e o próprio estilo de vida.

Henry D. Thoreau (1817-1862) nasceu em Concord, Massachusetts nos Estados Unidos. Junto do pensador Emerson participou do movimento transcendentalista, que "inspirou grandes nomes para a volta a uma vida equilibrada, em profundo contato com a natureza e em harmonia com a essência humana" (CASCINO, 2000a, p. 23).

Atualmente Thoreau é conhecido por conta de 'A desobediência civil', um de seus principais escritos. Thoreau afirmou que não bastava recusar-se a participar da guerra como soldado, mas que era necessário também não colaborar com o pagamento dos impostos que seriam utilizados na compra de armamentos. Um de seus mais profundos pensamentos a cerca da Desobediência Civil diz que "o que me cumpre é ver se de algum modo não estou contribuindo para o erro que condeno" (THOREAU, 2001, p. 331). Podemos transportar tal pensamento hoje para a Educação Ambiental em relação ao consumismo e perguntar se os discursos ambientalistas e as correlatas práticas são coerentes. Discursamos sobre mudanças nos padrões de consumo e conforto, mas estamos prontos para agir neste sentido? 
Influenciado por Thoreau, Gandhi atua fundamentalmente para a libertação pacífica da Î́ndia do poder do maior império do século XIX, o Britânico. Assim, "pacifismo e desobediência civil terem caminhado tão juntos a ponto de serem quase sinônimos" (CASCINO, 2000a, p. 24).

Thoreau é considerado "avô espiritual" (CABRAL, 2001, p. 12) dos movimentos da década de 1960. Nesta época os jovens questionaram a civilização ocidental assim como ele fizera no século XIX. Entre tais jovens, a consciência pública sobre "o racismo institucional, a pobreza, a destruição ambiental e o materialismo impensado desencadeou uma onda de dissidência, ativismo político e desobediência civil em larga escala" (KIRK, 2008, p. 89). Tal influência é importante para todo o movimento ambientalista assim como para uma Educação Ambiental que pretenda "estimular a consciência pública" (KIRK, 2008, p. 38), assim como Thoreau o fez.

Acreditamos que se a Educação Ambiental tem como fundamento a transformação social, ela deve ter como princípios a desobediência civil e o questionamento aos mecanismos do sistema capitalista. Assim, a Desobediência Civil de Thoreau é um profundo marco (CASCINO, 2000a).

Além de A desobediência civil, Thoreau ficou igualmente conhecido por sua relação com a natureza. E embora o autor fosse avesso às comunidades (KIRK, 2008) ele é um dos ícones do movimento hippie. No tempo que passou em sua cabana junto ao lago de Walden, local que the serviu de inspiração para escrever sua obra mais famosa: Walden ou a Vida nos Bosques (2001), procurou na solidão de sua permanência refletir sua condição de humano e seu contato com a natureza. Diz ele que procurou o contato com a natureza indo aos bosques porque

pretendia viver deliberadamente, defrontar-me apenas com os fatos essenciais da vida, e ver se podia aprender o que tinha a me ensinar, em vez de descobrir à hora da morte que não tinha vivido. [...] Queria viver em profundidade e sugar toda a medula da vida, viver tão vigorosa e espartanamente a ponto de pôr em debanda tudo que não fosse vida. (THOREAU, 2001, p. 95).

Nesse contato com a natureza encontramos um fundamento para a importância do pensador como influência para uma Educação Ambiental não-formal no Ecoturismo. Ambientalismo, Ecoturismo e Educação Ambiental nascem no efervescente período da década de 1960 e recebem por parentesco a influência do autor.

\section{Visitas à natureza: o Ecoturismo como possível veículo para Educação Ambien- tal não-formal.}

Acreditamos que seja necessário reconhecer-se no contato com a natureza, afinal este é o espaço da gênese do ser humano. A visita ao ambiente natural - que aqui chamamos de visitas à natureza - possibilita o reencontro com o humano que há 
em nós que vivemos em alienação para as coisas da natureza. É no enfrentamento das adversidades típicas deste ambiente que se torna possível este encontro e a possibilidade de "desvelar sensações instintivas, sensibilidades oprimidas, encantamentos e pavores próprios de uma condição primitiva agora desaparecida". (CASCINO, 2000b, p. 203). A possibilidade de sensibilizar pessoas num ambiente natural e não controlado pode ser rica em oportunidades que possibilitem rupturas com 0 atual padrão de vida, que é baseado numa mentalidade consumista. Estas oportunidades podem induzir à "construção de novas leituras / discursos sobre nós mesmos, nossos prazeres, nossas crenças sobre o que somos, o que gostamos o que acreditamos" (CASCINO, 1998, p. 9). Isso coloca o ser humano frente a frente com o desafio de fazer uma releitura de si mesmo. Nas visitas à natureza, o contato com ambientes naturais, a busca por contemplação ou por adrenalina e superação pessoal etc. coloca sempre uma "possibilidade de ruptura com maneiras de sentir, de pensar e de conduzir nossas ações, com valores sedimentados por uma rotina e um estilo de vida que nos afastam de nossa condição animal / natural" (SERRANO, 2000, p. 17).

As operadoras ecoturísticas mostram seu desconforto quanto à possibilidade de promover atos educativos em seus pacotes de viagem, alegando que a inserção de discursos ambientalistas é fator de desgaste ao produto. Para elas isso se torna missão inviável, pois o momento de lazer proposto pela prática do Ecoturismo não combina com tal postura. Seria uma forma de se perder clientes. Frente a essa demanda, como tal trabalho pode criar oportunidades de desenvolver a consciência ambientalista discutida até aqui? A professora Rita Mendonça afirma que "talvez seja até por isso que as operadoras evitem o trabalho educativo, pois o que conhecem é a educação que não diverte, que não instiga, que não inspira" (MENDONÇA, 2005, p. 248).

Embora as operadoras tenham esta postura, podemos considerar o Ecoturismo como "estratégia privilegiada de educação" (SERRANO, 2001, p. 214). Um veículo apropriado para a prática da Educação Ambiental não-formal, por conta da informalidade de sua prática e pela força que os ambientes naturais têm na desestruturação de referências e condicionamentos sociais inscritos no corpo e nos hábitos de cada um. No ambiente natural, o ser humano pode entrar em contato com suas intuições e instintos. É lá que ele pode redescobrir sua capacidade de lidar com o inesperado, enfrentando seus medos (SERRANO, 2000, p. 17). O Ecoturismo não é a única maneira de se praticar a Educação Ambiental não-formal; ele é mais uma.

Os pressupostos do Tratado que analisamos anteriormente são a base para pensarmos relações entre a prática da Educação Ambiental não-formal e o Ecoturismo, se considerarmos que "a gênese de ambos os movimentos, considerando também o passado de ambos - a contracultura dos anos 1960 - é um caminho sólido, conceitualmente profundo" (CASCINO, 2000b, p. 204).

A prática de uma Educação Ambiental não-formal no Ecoturismo deve valer-se de momentos de contato entre os seres humanos e ambientes naturais na tentativa 
de sensibilizar os primeiros à compreensão da complexidade das relações que ali se desenrolam, para uma possível posterior mudança de atitude no cotidiano. Para o pesquisador Zysman Neiman o contato na natureza é "um elemento sensibilizador num primeiro momento. Para num segundo momento, haver uma reflexão da vida cotidiana das pessoas com a questão ambiental de uma maneira mais ampla" (NEIMAN). E completa: "levar [pessoas à natureza] tem que ter um motivo educacional" (NEIMAN).

No entanto, existe uma confusão quando se utiliza a palavra educação dentro da atividade ecoturística. O mercado ecoturístico a associa à educação formal. Por meio da atuação de profissionais, empresas e dos estudos acadêmicos, o Ecoturismo deve estar ligado a uma missão educacional que pense o ambiente em sua complexidade. Se for praticado de outra maneira é preferível chamá-lo de "turismo - o convencional - que passa despreocupadamente por cima das áreas que visita" (CASCINO; FIGUEIREDO, 2005, p. 550). É esse o caminho do Ecoturismo?

O Ecoturismo como veículo para a Educação Ambiental não-formal exige que se pense numa maneira proveitosa no sentido da experiência de se realizar visitas à natureza. Desenvolver visitas interessadas é fundamental para que se possa aproveitar o potencial educativo-ambiental dessas oportunidades.

As visitas interessadas são aquelas nas quais há a possibilidade de se mudar a relação com o espaço e o tempo, consigo mesmo e com os outros; para tanto, não devem ser realizadas de maneira superficial, por meio de comportamentos indiferentes ou agressivos que caracterizam o modo de vida nas cidades. As visitas marcadas por esses comportamentos tornam-se descompromissadas, representando um desperdício de oportunidades para o crescimento individual e são impactantes para o ambiente visitado, pois "os visitantes não interagem, apenas consomem paisagens" (MENDONÇA, 2005, p. 217-219). No sentido do consumo da experiência em ambientes naturais, para o homem moderno está distanciado da natureza e isso

faz com que ele não seja um observador. Ele é um consumidor. Ele consome com os olhos, consome com dinheiro, consome com o ouvido, mas ele não é um respeitador, um conhecedor da natureza [...] Ele vê a qualidade do belo, do bonito, é isso que 90\%, 80\% veem, querem ver o diferente, mas não é um diferente para conhecer, para respeitar. (DIEGUES)

O Ecoturismo é um possível veículo para uma educação que "oriente uma percepção mais ampla da realidade, que reconheça formas não racionais de aprendizagem e que saiba lidar com a imprevisibilidade da vida" (MENDONÇA; NEIMAN, 2005, p. 166).

O planejamento de estratégias educativas deve iniciar-se na intencionalidade de quem programa tais atividades, as operadoras ecoturísticas. Em tal planejamento não há a necessidade da incorporação de discursos ambientalistas. Estes não se fazem necessários. Todavia, a estratégia educativa deve ser bem planejada, requer es- 
tudo, fundamentação e constante revisão de sua prática. O profissional que se envolve com tais práticas, planejando seu trabalho sob tal fundamentação poderá realizar "um trabalho de maior responsabilidade social, e se tornará um agente transformador da qualidade de vida, e não um mero condutor de grupos de um lado para o outro" (MENDONÇA; NEIMAN, 2003, p. 72). É fundamental que os profissionais envolvidos com as atividades ecoturísticas - dos planejadores dos roteiros até aqueles que a executam - tenham em mente a necessidade da inserção do processo educativo.

Quanto ao planejamento dos roteiros ecoturísticos, a intencionalidade educacional por parte da operadora deve existir. Quanto à preocupação com a Educação Ambiental, Célia Serrano na entrevista de campo comenta que é "fundamental que a agência tenha a intenção e que ela propicie condições para esse toque à pessoa [afinal] tem uma coisa chamada roteiro que é fundamental para isso" (SERRANO). E Neiman completa dizendo que tais atividades devem ser realizadas "de maneira organizada, planejada, estudada, enfim, pesquisada." (NEIMAN).

Para que um roteiro ecoturístico seja bem elaborado é fundamental a participação da comunidade local. Neiman pergunta qual deve ser a "participação da comunidade local na elaboração do roteiro? O que a comunidade quer mostrar? Onde é que estão seus problemas, como é que eles aparecem? Onde está o debate quente da questão ambiental?" (NEIMAN). Pode haver assim, um benefício para a comunidade local com as práticas do Ecoturismo, mas, é necessário que quem viva na localidade seja chamado para "debater, planejar, participar" (NEIMAN). O professor pergunta sobre o debate participativo da operadora na comunidade local, pois "na hora de bolar os roteiros, o pessoal tem algo a dizer, de repente sai coisa muito interessante, se você convidar o povo a participar, bolar o seu próprio roteiro, participar dele" (NEIMAN).

O Professor Diegues comenta que um fator importante no sentido do planejamento, a respeito da participação das comunidades locais é fazer com que "estas populações se apropriem do turismo, isto é, que elas controlem o turismo [...] que elas possam dizer quantas pessoas podem chegar no fim de semana, qual é o limite do número destas pessoas" (DIEGUES).

Além das comunidades, em tal planejamento, o professor Neiman sugere que o mercado "precisa de um diálogo com a academia para não cometer erros banais na implantação de um turismo que acaba sendo um turismo convencional pintado de verde, porque vai virar consumo, vai virar produto" (NEIMAN).

Quanto à execução dos roteiros ecoturísticos, a figura do condutor de grupos é muito importante. No Brasil, os condutores de grupos são chamados de Guias de Turismo. Outros profissionais que trabalham com guiamento são os Monitores Ambientais. No Estado de São Paulo a Resolução SMA-32, de 31 de Março de 1.998 que "regulamenta a visitação pública e credenciamento de guias, agências, operadoras e monitores ambientais, para o Ecoturismo e Educação Ambiental nas unidades de conservação do Estado" (SÃO PAULO, 1998) institui a figura do monitor ambiental nas unidades de conservação da unidade da federação. 
Percebemos que para as operadoras entrevistadas, o papel do condutor de grupos é fundamental. A experiência do ecoturista passa fundamentalmente pela competência deste profissional. O representante da Operadora 1 comenta que "a escolha do guia adequado para cada perfil de visitante é uma coisa importante, a gente toma bastante cuidado com este item por entender que na hora da visitação é um profissional que faz a diferença total" (OP. 1) e complementa dizendo que não existe fórmula pronta para o trabalho do condutor e sendo que "como fazer é o desafio. Acho que isso não tem uma formula pronta. Eu acho que do ponto de vista do guia pega muito por características pessoais" (OP. 1).

Embora as características pessoais do condutor sejam importantes, acreditamos que não sejam suficientes para produzir um profissional que tenha condições de realizar as atividades de Educação Ambiental. É necessário estudo e preparação. A Operadora 1 aponta dizendo que "não existe uma escola de guia [...] não existe uma cultura do trabalho de guia, principalmente no ecológico, no turismo de aventura, muito clara, de qual é o papel deste guia" (OP. 1). A Operadora 2 diz que "o papel do guia é muito maior do que todo mundo pensa [...] é um trabalho de professor [...] com a diferença que ele está em campo" (OP. 2). A estes profissionais é atribuída a responsabilidade pelo sucesso ou fracasso de uma viagem. O representante da Operadora 3 apresenta também a contrapartida do papel do condutor quando este acaba causando a antipatia do visitante, pois "tem muito guia que quer mostrar que é bom. Ai o cara [o condutor] se torna desagradável. E ai você tem o mesmo problema, o cara [o ecoturista] que pega aversão do guia, ele não escuta o que o guia tem a dizer pois ele não gosta do guia" (OP. 3). Novamente reincidindo a questão da transmissão da informação como forma criticada de educação.

No caso do Ecoturismo, o condutor de grupos é, por vezes, um morador local e é quem conhece o lugar. Este deve ter uma postura de humildade (no sentido do respeito à compreensão do não-conhecimento do visitante em relação ao local visitado) para com aquele que desconhece o lugar e essa atitude de respeito frente aos visitantes deve estar "mergulhada no silêncio fecundo, gerador da dúvida e da vontade de conhecer, forças propulsoras da criação, razão primeira da realização da atividade" (CASCINO; FIGUEIREDO, 2005, p. 552).

Para favorecer uma experiência em ambiente natural, o condutor deve "desconhecer o lugar, para permitir ao guiado o direito de construir sua percepção sobre o próprio lugar" (CASCINO; FIGUEIREDO, 2005, p. 552). Isso tem um tempo que deve ser respeitado por parte de quem conduz a atividade. Este é um ponto de conflito entre o tempo necessário a tal construção e as demandas dos pacotes ecoturísticos.

No transcurso de tais atividades deve haver muita atenção à questão da transmissão de informações. As informações que são apenas transferidas, logo se apagam da memória das pessoas e não conseguem produzir uma modificação em seu comportamento. Reconhecemos que se algum tipo de informação é necessária, esta deve ser transmitida "de forma a não desautorizar os sentimentos" (MENDONÇA, 2005, p. 
248). As possibilidades de aprendizado não são criadas a partir apenas da transmissão de informações. As sensações percebidas em um ambiente natural são proporcionadas por diferentes sons, texturas, cores, aromas, típicos daquele lugar e que normalmente não são mais vivenciados em cidades. A percepção destes é um exercício que deve ser estimulado em todos os visitantes. O papel do condutor é criar condições para que os participantes da atividade possam estar no local "não só fisicamente, mas mentalmente também" (MENDONÇA, 2005, p. 248).

$\mathrm{O}$ passeio deve fluir de maneira livre, deixando o visitante construir suas impressões sobre o local, gente, cultura etc. a partir de seu referencial. É o momento do (re)conhecimento do local por parte de quem o visita.

A interpretação se dará no momento posterior ao da experiência da visita. A interpretação é "a construção crítica derivada da experimentação. Dá-se como tempo e lugar posterior, de elaboração. É posterior ao ato. É razão sobre emoção" (CASCINO; FIGUEIREDO, 2005, p. 552).

Ao final da experiência, a reflexão sobre a mesma, sobre o que ali foi vivido. $O$ condutor dos visitantes tem o papel de provocá-la. Uma conversa com os participantes da atividade para livremente apresentarem suas impressões sobre o vivido: emoções, sentimentos, sensações vividas durante o passeio. Uma proposta como essa "confere múltiplas dimensões a interpretação do local, passando a vivência, a habitar um espaço de reconhecimento das múltiplas vertentes de liberdade" (CASCINO; FIGUEIREDO, 2005, p. 552). A criação de um ambiente de debates neste momento é uma possibilidade de síntese a ser atingida em diferentes níveis pelos visitantes quando "as informações são combinadas com reflexões, e quando as emoções e impulsos podem ser observados e redirecionados para ações que priorizam o bem comum" (MENDONÇA, 2005, p. 25).

O contato entre pessoas e natureza pode trazer consigo possibilidades de aprendizado. Não uma simples incursão sem preparo em um ambiente natural, mas por meio de atividades devidamente estudadas e planejadas.

A necessidade de se vivenciar experiências em ambientes naturais leva o homem moderno (pós-moderno?) a buscar tal contato. O sistema capitalista vê nesta necessidade mais uma oportunidade de transformá-la em mercadoria.

\section{O ECOTURISMO COMO MERCADORIA E ESPETÁCULO}

O Ecoturismo apropria-se das características do ambiente, elementos tangíveis e intangíveis, do lugar e sociedade ao compor seu produto, convertendo toda possível diferença em mercadoria. Isso se dá na conversão de recursos em atrativos turísticos, que a tendência hegemônica chama de "oferta primordial" (ANSARAH, 2001, p. 24).

Mercadorias como botas, cantis, camisetas, calças, meias, barracas, veículos 4x4 são exemplos corriqueiros praticamente 'obrigatórios' para as práticas do ecotu- 
rista. No entanto, na cultura de consumo o Ecoturismo é uma busca incessante por transformar qualquer coisa que não seja necessariamente uma mercadoria em algo vendável em algum mercado. Assim, o Ecoturismo tal qual o turismo procura "promover a 'venda' da natureza, das construções históricas, das manifestações folclóricas" (OURIQUES, 2005, p. 49), produzindo o desejo de consumo de tais bens.

O Ecoturismo é o consumo dos atrativos, ou de imagens, pois o uso de tais lugares não é direto e sim contemplativo: não se leva o atrativo para casa, o consumo da imagem é feito no local. No Ecoturismo como atividade espetacular, a visão é o sentido mais utilizado, pois é o "mais abstrato e mais passível de mistificação" (DEBORD, 2004, p. 18). Isso é primordial para o entendimento do Ecoturismo. Embora haja até mesmo certa interação com os locais ao se fazer uma trilha, descer uma cachoeira, explorar uma caverna, visitar a casa de um morador local, estas interações se dão de forma passageira. Ao final, leva-se para casa lembranças ou suvenires comprados no local. O Ecoturismo transforma a consciência das pessoas em consumidoras da natureza: ecoturistas. Torna-se então mais um produtor de consciências conformadas ao consumo. Um público específico, um nicho de mercado nos dizeres do marketing falando sobre a segmentação do público consumidor.

O tempo das comunidades receptoras é transformado em mercadoria, adequando-o ao tempo do capital, por meio de roteiros pré-formatados de acordo com a disponibilidade do cliente-turista-pagante. A relação das comunidades com o tempo é adequada à pseudo-ciclicidade do tempo do capital (DEBORD, 2004).

Na cultura de consumo, a atividade ecoturística é uma metáfora da sociedade do espetáculo, pois é bastante evidente a presença de mecanismos espetaculares como a transformação, revalorização e ressignificação das coisas, lugares e acontecimentos para a venda sob forma de pacotes pelo Ecoturismo. Pode se perceber que praticamente tudo pode ser atrativo turístico. Essa produção (reprodução?) do turismo é um fenômeno ininterrupto que obedece a um mecanismo de renovação da apresentação de pseudonovidades sob a forma de lançamentos de novos pacotes com destinos 'exóticos'. Assim como nos dizeres de Debord "por esse movimento essencial do espetáculo, que consiste em retomar nele tudo o que existia na atividade humana em estado fluido, para possuí-lo em estado coagulado" (DEBORD, 2004, p. 112).

A questão da cultura de consumo não é abordada nos livros escritos pelos estudiosos que analisam o turismo no Brasil, do ponto de vista econômico, desconsiderando as questões expostas.

O tema natureza é apelo reincidente no Ecoturismo e deve ser compreendido como uma de suas principais apropriações, por conta da Educação Ambiental no Ecoturismo dar-se no suposto contato entre seres humanos e natureza. O Ecoturismo relaciona-se com o mercado turístico na forma do consumo da natureza (RODRIGUES, 2000, p. 173-180). Natureza tem a origem etimológica no latim natura que em essência significa "a natureza personificada, o princípio criador, essência das coisas, caráter, propriedade, índole, instinto" (HOUAISS, 2001, p. 1998). O ser humano sempre procurou seu significado (LENOBLE, 1990, p. 27). O que conhecemos por natureza é 
uma criação da própria cultura. É um conceito social, historicamente construído. Afinal, para o ser humano ela pode assumir várias interpretações: é a "vontade dos deuses do mar, [...] uma hierarquia de formas organizadas; [...] uma máquina, mãe [...] admirável e terrível" (LENOBLE, 1990, p. 28-29). Cada época da história formou sua concepção sobre o assunto. Mas quais serão suas concepções nos dias atuais?

$\mathrm{Na}$ busca de resposta para esta pergunta, procuramos orientação nas crenças judaico-cristãs que estão fortemente enraizadas na vida ocidental moderna. Nossa concepção de natureza passa por tais filtros. E sob tal convicção, esta foi criada por Deus que dá ao homem a incumbência de nomear todas as coisas na terra, pois havendo Deus "formado da terra todos os animais do campo, e todas as aves dos céus, trouxe-os ao homem, para ver como este Ihes chamaria; e o nome que o homem desse a todos os seres viventes, esse seria o nome deles" (GÊNESIS, II, v. 19). Assim, Deus cria materialmente a natureza e tudo o que nela há, e o homem a cria simbolicamente, através dos nomes. E não havia distinção entre homem e natureza, pois todos compartilhavam do mesmo jardim, da mesma perfeição.

Com a queda do homem e da mulher "abriram-se, então, os olhos de ambos; $e$ percebendo que estavam nus, coseram folhas de figueira, e fizeram cintas para si" (GÊNESIS, III, v. 7), passando a partir deste momento, a observar a natureza de fora. O homem, criação máxima de Deus, perde o paraíso na terra. Inicia-se ai, a busca pelo (re)encontro. A metáfora do jardim, no sentido de paraíso e de sagrado, é comumente utilizada pela mídia para a venda pelo Ecoturismo das localidades supostamente intocadas pelo ser humano para a realização das práticas ecoturísticas. Simbolicamente, a 'queda' do ser humano é sua cisão com a natureza. A partir deste fato, o domínio da natureza pela humanidade exigirá esforço, ciência e trabalho.

O desenvolvimento da moderna ciência dessacralizou parcialmente o mundo e permitiu que o homem enxergasse a natureza como complexa máquina e decompôla, peça a peça, analisar suas partes para tentar compreender o todo, dominá-la, assim como Deus havia pré-dito. O homem não necessita mais do benefício divino, pois a partir de seu próprio esforço pode conseguir o paraíso. Pode agora criá-lo e recriálo.

O olhar humano é fundamental na relação com a natureza, pois este observa e valora a natureza de diversas maneiras. As questões acima destacadas são essencialmente valorativas e "centrais para a consideração das concepções a respeito do mundo natural e das práticas em relação a ele" (WEARING; NEIL, 2001, p. 17). Há o valor da ética antropocêntrica, a ética do uso, que "vê os seres humanos como situados acima ou fora da natureza, como a fonte de todos os valores, e atribui apenas um valor instrumental, ou de 'uso' da natureza" (CAPRA, 1996, p. 25) assim a natureza toma valor pelo que ela pode proporcionar à humanidade e esta "é livre para empregar às suas próprias e variadas finalidades" (WEARING; NEIL, 2001, p. 17). Capra compara este tipo de pensamento à ecologia rasa (CAPRA, 1996). Há a visão ecocêntrica - que Capra (1996) associa à ecologia profunda - enxerga o valor intrínseco 
como sendo aquele que "existe por seu próprio direito, por sua natureza" (WEARING; NEIL, 2001, p. 17), uma ética da natureza, que "sustenta que as entidades nãohumanas são de valor igual ao da espécie humana" (WEARING; NEIL, 2001, p. 17).

Ao olharmos para o mundo atual percebemos que a ética de uso é a hegemôni$\mathrm{ca}$, tomando por base a relação que a sociedade ocidental atualmente tem com a natureza sob o discurso do crescimento econômico. Vamos conferir algumas das justificativas instrumentais para a conservação da natureza que são cortadas por tal viés. Assim, a natureza pode ser vista como (a) fonte de sentido para a vida (MENDONÇA, 2005) e referência ao belo: vista como uma catedral na qual seu valor é baseado na possibilidade do despertar espiritual e do deleite estético (WEARING; NEIL, 2001); (b) pode igualmente ser vista como fonte de recursos e ser comparada a um silo (WEARING; NEIL, 2001) no qual está estocada a diversidade genética, a biodiversidade; (c) pode ainda ser vista como laboratório e servir aos desígnios humanos como palco para as pesquisas científicas (WEARING; NEIL, 2001); (d) e por fim como ginásio de esportes no qual, "torna-se o local ideal para o turismo e a recreação" (WEARING; NEIL, 2001, p. 18).

Sob tal justificativa, a teoria do Ecoturismo alardeia a busca por uma natureza que é fundamentalmente diferente do lugar de onde parte o ecoturista, normalmente a cidade. A busca por uma natureza supostamente intocada, longe do contato humano, para ser (usu)fruída. Essa é a confirmação acerca do neomito da natureza intocada, pois "a natureza em estado puro não existe, e as regiões naturais apontadas pelos biogeógrafos usualmente correspondem a áreas extensivamente manipuladas pelos homens ao longo dos séculos" (DIEGUES, 2001, p. 86). Essa busca por um local intocado é normalmente qualificada nas propagandas sobre pacotes ecoturísticos como locais onde existem 'praias paradisíacas', sendo que 'muitas ainda desertas' nas quais você pode 'sentir as vibrações positivas' e pode encontrar 'plantas exóticas'. A figura do paraíso é reincidente. Tal busca é fundamental para o Ecoturismo e justifica o consumo da natureza por parte de seus praticantes.

A produção do Ecoturismo apela ao romantismo e resgata o passado e a natureza de maneira idealizada, abstraindo dela os problemas da difícil convivência que a humanidade encontra. Podemos perceber que é a mesma dinâmica que Keith Thomas descreve - referindo-se à Inglaterra do século XVII - dizendo que a separação entre a cidade e o campo "encorajou esse anseio sentimental pelos prazeres rurais e a idealização dos atrativos espirituais e estéticos do campo" (THOMAS, 1988, p. 297).

Quanto maior a urbanização, maior a busca por uma natureza supostamente intocada. O mesmo autor mostra que a busca da natureza via turismo já se desenvolvia, pois se referindo aos períodos de lazer e pequenas viagens, comenta que "o maior conforto na vida cotidiana tornava as provações mais árduas - desde que ocasionais - mais atraentes para as classes médias em férias" (THOMAS, 1989, p. 310).

Em tempos da modernidade líquida a natureza é concebida como mercadoria pela cultura de consumo na sociedade do espetáculo e é mercantilizada como atrativo, por meio do Ecoturismo que Ihe atribui novos significados. A cultura de consumo 
tem como premissa a expansão da produção de mercadorias, que dá origem a uma cultura material na forma de bens e locais de compra e consumo (FEATHERSTONE, 1995, p. 31). Dentre tais locais, a natureza parece ser a nova fronteira a ser desbravada, pois é nesse desbravamento que deve ser revivida a busca pelo paraíso perdido e desafio que resulta da 'queda'. Estamos neste momento em camadas profundas da subjetividade humana. Quando pensamos nesta estratégia, percebemos a tendência da utilização do uso dos processos de consciência ambiental para vender novos produtos; o Ecoturismo amplia tais territórios, invadindo natureza e subjetividade humana.

\section{ECOTURISMO: REAFIRMAÇÃO DO TURISMO CONVENCIONAL}

O Ecoturismo é conceituado em ampla bibliografia como alternativa ao turismo convencional: o quesito educacional, a preocupação com a questão da conservação do ambiente visitado, o envolvimento das comunidades locais em sua operação etc. Agregando o material coletado nas entrevistas, apontaremos alguns motivos para uma reflexão sobre o papel do Ecoturismo como reafirmação do turismo convencional.

O mercado de turismo tem sua lógica coagida pela dinâmica do lucro de curto prazo e não respeita a sustentabilidade social, cultural ou ecológica de longo prazo (WEARING; NEIL, 2000, p. ix). O Ecoturismo, segmento do turismo, obedece à mesma lógica e "vai ser colocado por alguns de seus críticos entre tais produtos 'esverdeados' para o consumo das classes médias" (SERRANO, 2000, p. 11), e corre o risco de ser manobrado por ações fundamentadas apenas na busca do lucro (CASCINO, 2000b). Alguns representantes do trade turístico levados pelo oportunismo usam "a ecologização, de forma superficial e não comprometida, como ingrediente 'esverdeante' de seus negócios ou projetos em torno do (eco)turismo" (PIRES, 2005, p. 163). Tal apropriação é favorecida pela imprecisão semântica e pelo descolamento conceitual que o Ecoturismo sofre por conta da ação dos condicionantes da pósmodernidade já anteriormente citados, com sua consequente pulverização para utilização do mercado turístico. Muitas operadoras turísticas têm se utilizado do ambiente natural apenas como cenário para a realização das atividades (PIRES, 2002, p. 161).

Em muitos casos, a utilização do prefixo eco- funciona como a redenção do termo ao qual é encampado, como um sedativo para a consciência das classes médias. O uso mercadológico de eco- funciona como uma nova roupagem para o que ainda pode ser antigo. Tudo agora é eco-. Ser ecologicamente correto está definitivamente na moda, no entanto, esta postura traz cobranças e a Operadora 1 queixa-se disso. Neste sentido quando uma operadora se apresenta como ecoturística ou mesmo de turismo de aventura "em geral a mídia te pergunta se você é consciente. Ninguém pergunta isso para uma grande rede hoteleira, para uma CVC. Deveria perguntar, pois o grande impacto vem do grande capital". (OP. 1). Há em tais dizeres, que a responsabilidade pelo grande impacto é proveniente do grande capital na figura das grandes operadoras e implicitamente, se dá a entender que operadoras de pequeno 
porte não comungam de tal responsabilidade.

Para tal operadora a segurança (item que consideramos essencial à prática do Ecoturismo) e o conforto são diferenciais de seu produto. Essa "é a ideia do Ecoturismo: tratar bem o cliente, não é tratar mal o cliente em troco de uma experiência na natureza. Não. É ter o máximo de experiência na natureza, mas com bom serviço". (OP. 1). A questão do conforto pode subverter os pressupostos do Ecoturismo (baseados na sustentabilidade, na educação e na relação com as comunidades locais).

O objetivo do Ecoturismo-mercadoria é tratar bem o cliente em primeiro lugar, pois é ele o ator que participa pagando pelos serviços. É por meio do cliente que vem o dinheiro. Sabemos que o Ecoturismo como um segmento de mercado do turismo tem como objetivo a exploração turística de ambientes naturais. Para que tal atividade exista com a segurança e o conforto requeridos pela operadora torna-se necessária a adaptação do local visitado. Porém é o comportamento do ecoturista que deveria ser "determinado segundo o meio ambiente" (WEARING; NEIL, 2001), afinal é isso que o diferencia do turista convencional que adapta o meio a seu comportamento usual.

O que pudemos observar em nossas entrevistas é que essa prerrogativa nem sempre é cumprida. A Operadora 1 considera que experiência ecoturística é bem sucedida quando o ecoturista tem um hotel no qual ele pode chegar à noite "ligar um ar condicionado e dormir bem. Ele vai acordar mais disposto e entender que aquele é um destino legal e se a experiência toda de visitação dele é uma experiência positiva, ele gera um sentimento mais positivo em relação ao ambiente" (OP. 1). O ar condicionado como conforto é abordado pela operadora como um diferencial que pode ajudar o turista a perceber que aquele lugar, chamado de destino por tal operador é legal e que isso pode inclusive auxiliar numa experiência mais positiva. A experiência de consumir um produto de qualidade fica clara aqui como fundamental para que o cliente I turista possa ter um suposto sentimento mais positivo em relação ao ambiente ou ao produto que ele comprou. Segundo tal visão, a experiência positiva depende da alteração do ambiente por meio da implantação do sistema de ar condicionado, entre outros recursos que na verdade mascaram a realidade local. Como afirma Neiman "pintar de verde o produto é muito fácil, dá um dinheirinho aqui, [...] contrata o cara local e diz que está ajudando à comunidade, pronto! Mas na hora que o cliente ligar, mas tem frigobar? [...] fica forçando a barra para o serviço local ser padronizado" (NEIMAN).

A padronização do serviço local, a adaptação dos ambientes visitados, sejam eles cavernas, lagos ou residências de moradores é um fato no planejamento do Ecoturismo que pensa no ecoturista como cliente e em primeiro lugar em comparação à comunidade e ambiente que a ele devem se adaptar. Outro ponto importante é que toda esta adaptação acaba por mascarar a realidade local e é o próprio visitante que fica impossibilitado de uma troca mais real com o estar / sentir aquela experiência, pois está cercado da mesma parafernália que deixou em sua residência.

Podemos comparar o turismo ao cinema (MORIN, 2000), pelo fato do primeiro 
ser uma forma de mercantilização das experiências que envolvem uma percepção esteticamente mediada (FEATHERSTONE, 1995). A Operadora 1 procura "preparar a visita na hora mais bonita mesmo, na hora em que o sol está batendo na cachoeira, que um raio de luz está entrando numa gruta" (OP. 1) para proporcionar a melhor experiência aos seus turistas a fim de gerar "um vínculo com a região selvagem que também é educação" (OPERADORA 1). O simulacro não está restrito aos ambientes das cidades, está nas atividades na natureza que buscam o risco controlado (SERRANO, 2000), como as do Ecoturismo em sua vertente de aventura. O Ecoturismo apresenta-se como reafirmação do individualismo, característica marcante de nosso tempo, mesmo que "se revista de uma aura de auto-conhecimento/ espiritualização" (SERRANO, 2000, p. 15). A Operadora 2 acredita na contraposição entre o turismo convencional e o Ecoturismo, como atividade que leva pessoas para contato com a natureza em uma experiência necessária e diferente do primeiro, que aí sim é o simulacro. Para sua representante o contato com a natureza é algo necessário. O turismo convencional apresenta um show típico que não tem, na verdade, nada de típico, é "tudo uma grande montagem [...] a ideia é fazer outra coisa, é trazer as pessoas no contato com a cultura nativa, a natureza que a gente entende como um processo fundamental para o ser humano esse contato" (OPERADORA 2).

A busca por novas experiências (WEARING; NEIL, 2001) é ponto comum entre os dois tipos de turismo. Podemos questionar o Ecoturismo em seu pretenso caráter de alternativo frente ao turismo convencional, afinal os interesses dos ecoturistas por tradições, etnias e natureza são manipulados pelo marketing ecoturístico que "contribui para a (re)invenção dessas mesmas tradições, exotismos e temporalidades" (SERRANO, 2000, p. 16). A busca pelo consumo da experiência no Ecoturismo aproxima-o do turismo convencional.

Para Neiman, muitos roteiros de mercado acabam por impermeabilizar a experiência do ecoturista, comentando acerca da realidade local, dos problemas vivenciados e de uma possível troca de experiências entre visitantes e visitados. Nos pacotes de Ecoturismo, muitas vezes o ecoturista durante sua visita "é impermeabilizado em relação a estas questões" (NEIMAN). O professor completa dizendo que as operadoras colocam o turista "numa pousada linda, maravilhosa e charmosa, te põem lá no roteiro, você vai com o guia pra lá e pra cá, e você fica meio impermeabilizado para sacar estas coisas, o roteiro não te favorece isso, enquanto que eu acho que deveria ser uma obrigação" (NEIMAN).

Dentro dos limites desta pesquisa, quanto à questão do planejamento das atividades educacionais, há uma espécie de consenso sobre o não embasamento conceitual de tais atividades por eles praticadas. Nenhuma das operadoras entrevistadas tem preocupações com a elaboração teórico-conceitual de atividades educativas em seus pacotes ecoturísticos. O representante da Operadora 1 comenta a esse respeito dizendo que "a gente lê muito hoje em dia, mas posso te dizer que ninguém se preparou para começar isso... a gente foi aprendendo meio na marra, um pouco por sensibilidade, por querer agradar o visitante, e fazer a coisa direita" (OP. 1). E completa di- 
zendo que "a gente nunca leu grandes tratados de turismo. [...] Nós não temos nenhuma linha filosófica a seguir. [...] A gente é mais empírico" (OP. 1). No entanto, a operadora em questão procura trabalhar a educação de seus clientes por meio de materiais com informação - apostilas - que procura distribuir aos visitantes. Segundo seu representante "em alguns momentos, não posso dizer que seja uma prática constante, mas a gente, em alguns momentos, elabora materiais que a gente procura distribuir aos visitantes" (OP. 1). E complementa dizendo que "essa apostila está ambientada na época que estava se falando com ênfase em construir a hidrovia Paraguai-Paraná, que é um projeto de altíssimo impacto ambiental e que o setor do turismo todo na região se mobilizou" (OP. 1)

Existe a crença de que através de manuais ou materiais impressos se faz Educação Ambiental por meio da transmissão de informações a respeito do destino e de sua complexidade. Este tipo de material pode ser utilizado se for associado a outras ações educativas. Limitar-se à utilização de apostilas, dificulta o aprofundamento das temáticas complexas que a viagem em si pode motivar por meio da intencionalidade educativa da operadora. O ambiente a ser visitado é propício a outros tipos de atividades que privilegiem outras formas de educação, como a sensibilização.

A produção deste tipo de material é uma prática espetacular, pois o setor do turismo mobilizou-se pela questão da hidrovia Paraguai-Paraná, pois esta afetaria diretamente seus negócios. Assim, com ares de defensoras do meio ambiente, as empresas interessadas na manutenção de sua área de exploração turística unem-se pela causa, produzindo apostilas para entregar a seus visitantes, agregado a causa ambiental (luta pela não implantação da hidrovia) ao seu logotipo.

A respeito da fundamentação teórica para atividades educativas em seus pacotes, a Operadora 2 comenta que eles trabalham com a experiência de mercado, "conversando, indo e participando, eventos aqui e ali, governo, e tal [...] muito de prática, é muito do dia-a-dia, no que a gente escuta, no que a gente conversa, vai a campo para ver, [...] com a imprensa, uma relação bacana com a imprensa" (OP. 2). E completa dizendo que "a gente vai fazendo basicamente em cima da experiência de mercado" (OP. 2). Fica bastante evidente que a experiência de mercado e da relação com outros parceiros é fundamental para a operadora em questão. A fundamentação teórica não é parte da prática desta empresa.

Há até mesmo aversão quanto ao tratamento conceitual das atividades educacionais, conforme nos aponta o representante da Operadora 3 que diz que tem "um pouco de aversão a essas questões conceituais todas" (OP. 3). Mas, o representante afirma que se propõe a levar as pessoas com todo respeito para um contato harmonioso, uma integração com o meio ambiente. E diz: "Eu não tenho a menor dúvida que fazendo este trabalho eu tenho a oportunidade de estar tocando as pessoas, dando alguns toques principalmente através da atitude, da postura" (OP. 3).

Nas entrevistas, os representantes das operadoras mostraram seu incômodo com a questão da forma de se trabalhar questões educacionais por parte dos condutores de grupo no Ecoturismo. Há certa fixação na informação, na transmissão da in- 
formação. A Educação Ambiental não-formal no caso do Ecoturismo deve ser bastante diferenciada da descrita por tal operadora. É necessário procurar formas alternativas de abordagem para tais práticas. Por parte das operadoras, há a percepção de que caminhos não devem ser tomados. Acreditamos que este é um ponto importante para reforçarmos que o diálogo entre mercado e academia deve ser intensificado.

Sem preocupação com a Educação Ambiental, o Ecoturismo apenas reafirma as práticas do turismo convencional, pois os visitantes apenas passam pelos lugares e pessoas. Apenas como lazer, fuga, válvula de escape à vida da cidade.

\section{CONSIDERAÇÕES FINAIS}

Buscamos com este trabalho saber quais são os limites de uma Educação Ambiental exercitada nas práticas mercadológicas do Ecoturismo na cultura de consumo. A cultura de consumo produz mercadorias que satisfaçam e que renovem constantemente as necessidades. Célia Serrano afirmou que "não há como não consumir" (SERRANO). A mediação do mercado é um fato. Por isso perguntamos sobre os limites de uma Educação Ambiental exercitada nas práticas mercadológicas do Ecoturismo na cultura de consumo. Ouriques (2005) promove a crítica e a desconstrução, Freire $(2000,2001,2002)$ diz importante apontarmos caminhos para a construção do novo. Há que se denunciar o presente, há que se anunciar um futuro melhor (FREIRE, 2000). Apresentamos considerações das relações aqui debatidas.

Sabemos que os resultados da presente pesquisa têm limites (a realização de uma pesquisa qualitativa com 3 operadoras) e que tal pesquisa deve ser ampliada e reavaliada.

O significado do Ecoturismo: A constatação de alguns dos efeitos da velocidade, fragmentação e superficialidade pós-modernas nos parece significativa. O conceito polissêmico do Ecoturismo é um dos mais discutidos dentro do ramo do turismo, especialmente entre a academia e o mercado. De sua concepção original até as diversas práticas de mercado, o conceito de Ecoturismo teve grande variação de significados, permitindo que muitas atividades turísticas definidas por segmentos com interesses específicos em sua prática, pudessem ser colocadas sob tal 'guarda-chuva'. Ele une o ambientalismo, com um discurso que aborda (ou deveria abordar) assuntos delicados nos dias atuais como a questão da conservação do meio ambiente, da responsabilidade social (para com as comunidades envolvidas) e da Educação Ambiental, e o turismo que se dá pela exploração comercial de lugares, comunidades, tradições etc. e que é realizado em momentos de lazer e descontração dos turistas.

A questão da polissemia do Ecoturismo merece ser analisada com maior profundidade. O descolamento conceitual do Ecoturismo é causado pela condição de "mudança constante, rápida e permanente" (HALL, 2005, p.14) de nosso tempo. Na contemporaneidade e sob seus condicionantes, poucos sabem o que significa Ecoturismo, este "é um termo amplo e vago" (WEARING; NEIL, 2001, p. xvii). 
A não percepção do que representa a polissemia do Ecoturismo por parte dos teóricos das linhas hegemônicas de análise do turismo aponta para algo mais profundo, cuja compreensão não é imediata. Isso é um indicador do direcionamento das abordagens atualmente desenvolvidas no campo do estudo acadêmico do turismo e igualmente pode indicar a superficialidade da abordagem pelo mercado que é simplificador por conta de sua estruturação e não deseja que haja aprofundamento em questões relevantes. O Ecoturismo ter vários significados nos parece uma boa estratégia para que suas preocupações originais não sejam mais perseguidas e assim possa se entregar ao grande objetivo do capital: a busca do lucro de qualquer forma.

Podemos perceber que a fragmentação da pós-modernidade é reforçada pelo olhar da Operadora 2 para a qual o local visitado pelos ecoturistas é outro mundo. Para ela, o Ecoturismo se dá quando o turista "consegue sair do seu mundo e verdadeiramente entrar num outro universo, que não está ligado só a natureza, plantas, mato, bicho, mas realmente a uma nova vivência, uma vivência diferente" (OP. 2). Este pensamento aposta no ideário de outros mundos diferentes do nosso marcado pelo consumo excessivo, pela violência etc., mas pouco diz sobre a possibilidade da reflexão e da mudança de comportamentos 'neste mundo'.

A superficialidade está presente nos materiais didáticos apresentados pela Operadora 1 e nas palestras oferecidas pela Operadora 2 como fontes de informações. Estas reforçam a fragmentação da informação sobre os ambientes visitados, dificultando a compreensão de sua complexidade.

Embora as operadoras rejeitem a ideia da prática educacional durante seus pacotes por consideraram a educação como algo formal, elas ora apresentam apostilas e manuais, ora realizam palestras - ambas as práticas de um sistema formal de ensino. No entanto, não podemos desprezar tais ações. Este tipo de material pode complementar outras ações, tornando-se parte de um programa maior, uma intencionalidade educacional ampla.

Fundamentação teórica do trabalho de educação nas atividades ecoturísticas: Com base nas três entrevistas realizadas, constatamos que não há embasamento teórico para a ação das operadoras, todas se utilizam da própria experiência como base as ações. A falta de tal preocupação é decorrência da dinâmica do dia-adia do mercado que impõe demandas que tais operadoras consideram mais importantes que a educação. É o tempo do mercado sobrepondo-se ao tempo da educação. Isso traz um problema que deve ser apontado, pois o interesse do mercado é o lucro e a "a desatenção a esses elementos conceituais e históricos favorece manobras, manipulação" (CASCINO, 2000b, p. 205)

As operadoras acreditam que educação, por ser um processo chato e desmotivante e, por isso mesmo, não combina com turismo. Elas acreditam nisso porque se criaram na prática - sem estudo formal, detido e aprofundado. Além de apostilas e palestras, as operadoras promovem de maneira não organizada 'algum tipo de educação' apostando na ação dos condutores de grupos que atuam como parceiros. Os representantes das operadoras mostraram ter boa vontade e acreditar naquilo que 
fazem. As três operadoras iniciaram suas atividades por projetos pessoais.

Acreditamos que todas elas têm a ganhar se considerarem que a educação a ser praticada nas atividades ecoturísticas não é a da transmissão de informações que todas elas criticaram. Falta às operadoras compreenderem que a Educação Ambiental não-formal é exatamente aquela praticada em outros ambientes - como naqueles em que elas atuam. Os representantes das operadoras têm a intenção de desenvolver seus pacotes de maneira respeitosa para com o meio e para com as pessoas. Se a intencionalidade do ato educativo for deixada ao capital, não haverá formação de uma consciência ambientalista, mas sim de uma consciência conformada ao consumo.

A posição da academia: A academia não deve limitar-se a observar o Ecoturismo do ponto de vista econômico, do mercado ou de possíveis benefícios / malefícios que sua prática possa trazer. Os estudos científicos da tendência hegemônica de análise do turismo não compreendem a cultura de consumo e suas consequências. Compreender o que o Ecoturismo representa na sociedade de consumo possibilitará uma apreensão maior de sua complexidade. A educação para o turismo não precisa, nem deve ser apenas instrumentadora e apresentada como um manual de boas práticas para que as pessoas possam encaixar-se nas demandas de um mercado.

O livro Educando os Educadores em Turismo: manual de educação em turismo e hospitalidade (2001 - OMT e Universidade de Surrey / Editora Roca) não faz nenhum tipo de menção ao turismo como participante da sociedade de consumo. Por que a OMT não se preocupa em desvelar ideologias do consumo no turismo? Como é possível transformar a experiência do turismo em possibilidade educativa significativa se se encontra dificuldade em se preparar profissionais? É necessário considerar o turismo mais que um fenômeno meramente econômico.

A necessidade de diálogo entre academia e mercado: Deverá haver uma maior aproximação entre mercado e academia. Nesta tese, o professor Neiman acrescenta que tal diálogo seria muito produtivo, pois de um lado fica "a academia acreditando numa forma que eu acho muito distante da realidade do que é ser educacional, e o mercado não compreendendo que o educacional pode ser incorporado sem ser chato" (NEIMAN). O planejamento das atividades educacionais no Ecoturismo deve ser desenvolvido com profundo embasamento científico, filosófico, sociológico, antropológico etc. Sem fundamentação teórica e sem um estudo científico fica difícil qualquer ação educativa levar em consideração a complexidade dos lugares e situações abordados ou vividos durante qualquer visita. A velocidade com que as coisas acontecem na pós-modernidade dificulta o aprofundamento do estudo das questões essenciais. O mercado tem pressa. A academia, por sua vez sob a ideologia do estudo do empreendedorismo, acompanha o mercado, limitando-se a produzir planos de negócios etc. para viabilizar as atividades daquele.

Imposição de tempos espetaculares pelo capital: $O$ tempo dos pacotes de Ecoturismo pode reforçar o tempo pseudocíclico do capital por meio da programação do pacote elaborada anteriormente por um perito da operadora, reforçando assim a 
pseudo-ciclicidade do tempo do capital para os ecoturistas, pois estes vivem a "afirmação onipresente da escolha já feita na produção, e o consumo que decorre desta escolha" (DEBORD, 2004, p. 14-15); tal tempo pseudocíclico também invade e molda o tempo das comunidades receptoras. A ação dos condutores levando os turistas nos passeios e conduzindo sua experiência pode complementar tal mecanismo. A viagem acaba por obedecer aos mesmos ritmos da vida cotidiana dos ecoturistas. Nas comunidades receptoras, a imposição vem na necessidade da adequação de seu modus vivendi e de seu lugar de vida para o atendimento às demandas das operadoras e seus clientes.

O Ecoturismo como atividade compensatória e como válvula de escape: Com base em nossa pesquisa podemos considerar que nestes casos o Ecoturismo tenha funcionado como atividade compensatória e válvula de escape da vida alienada das pessoas: tendo assim função alienante. Serrano aponta em nossa entrevista que as "pessoas escapam de forma diferente. Escapar para a natureza é mais uma forma de escape, é a que chama mais a atenção pelo contraponto do espaço, o ambiente construído e o ambiente 'natural"' (SERRANO). A atividade compensatória é aquela que pode impedir a tomada de decisão para uma mudança realmente significativa e criar uma consciência conformista em seus participantes. Ao invés disso, precisamos é que "vingue uma rebeldia revigorada" (CASCINO, HINTZE, no prelo) e que as práticas do Ecoturismo possam contribuir para possibilitar consciências críticas.

Os representantes das operadoras concordam que não há Ecoturismo se for levada em consideração toda sua conceituação tal como foi vista. O proprietário da Operadora 1 diz é "muito difícil isso hoje [...] não temos nenhum destino que está acabado como um destino completamente, 100\% Ecoturismo, 100\% sustentável na prática, na operação, na distribuição de renda" (OP. 1), nem se quer na questão educacional. As operadoras do mercado podem ocupar os espaços da educação não-formal por meio das atividades de Educação Ambiental nas práticas ecoturísticas, formando pessoas para tal exercício. O envolvidos no processo devem manter-se sob revisão permanente da coerência entre falas e ações. A prática do Ecoturismo com a Educação Ambiental pode ajudar a "refletir mudanças nas tradicionais instituições promotoras e difusoras de práticas educativas" (CASCINO, 2000b, p. 197-198).

Reafirmamos que sabemos dos limites da presente pesquisa. A mesma deve ser continuada e refeita com outros pesquisadores e outras operadoras para que se possa gerar uma base de dados empíricos mais abrangente.

Por isto tudo é que devemos continuar a acreditar, denunciar, anunciar e agir.

\section{REFERÊNCIAS BIBLIOGRÁFICAS}

ANDRADE, J.V. Turismo: fundamentos e dimensões. São Paulo: Ática, 1997. 215 p.

ANSARAH. M.G.R. Turismo como ensinar, como aprender. São Paulo: Ed. SENAC, 2001. v. 2. 406 p. 
Hintze, H.C.

BAUMAN, Z. Modernidade líquida. Rio de Janeiro: Jorge Zahar Editora, 2001. 258 p. . Vida líquida. Rio de Janeiro: Jorge Zahar Editora. 2007. 210 p.

BENI, M.C. Análise estrutural do turismo. 9. ed. São Paulo: SENAC, 2000. 523 p. BRASIL. EMBRATUR. Lei 8623 de 28 de janeiro de 1996. Disponível em: <http:/l www.mtur.gov.br>. Acesso em: 28/01/07.

. Grupo de Trabalho Interministerial MICT/MMA. Diretrizes para uma política nacional de Ecoturismo. Brasília: EMBRATUR, 1994. 48 p.

. Ministério da Educação. Lei no. 9795, de 27 de abril de 1999. Disponível em: <http://www.mma.gov.br>. Acesso em: 10/01/08.

CABRAL, A. Introdução. In THOREAU, H.D. Walden ou a vida nos bosques e a desobediência civil. São Paulo: Aquariana, 2001. p. 07-13

CANCLINI, N.G. Consumidores e cidadãos. 3. ed. Rio de Janeiro: Editora UFRJ, 1995. $266 \mathrm{p}$.

CAPRA, F. A teia da vida: uma nova compreensão científica dos sistemas vivos. São Paulo: Ed. CULTRIX, 1996. 256 p.

CASCINO, F.A. Do turismo convencional ao ecolazer. Debates Socioambientais, São Paulo, n. 9, p. 15-23. 1998.

Educação Ambiental: princípios, história, formação de professores. 2. ed. São Paulo: Editora SENAC, 2000a. 109 p.

. Pensando a relação entre Educação Ambiental e ecoturismo. In SERRANO, C.; BRUHNS, H.; LUCHIARI, M.T. (Org). Olhares contemporâneos sobre o turismo. Campinas: Papirus Editora, 2000b. p. 189-206.

CASCINO, F.A.; FIGUEIREDO, F. Comunidade e ecoturismo: outras leituras para a Educação Ambiental. In TRIGO, L.G.G. Análises regionais e globais do turismo brasileiro. São Paulo: Ed. ROCA. 2005. p. 547-554

CASCINO, F.A.; HINTZE, H. Pedagogia do desassossego Educação Ambiental: encontros e caminhos. Brasília: MMA, 2008. No prelo.

COOPER, C.; SHEPHERD, R., WESTLAKE J. Educando os educadores em turismo: manual de educação em turismo e hospitalidade. São Paulo: Ed. Roca, 2001. 202 p.

DEBORD, G. A sociedade do espetáculo: comentários sobre a sociedade do espetáculo. Rio de Janeiro: Ed. Contraponto, 2004. 238 p.

DIAS, G.F. Educação Ambiental: princípios e práticas. São Paulo:Ed. Gaia, 2003. 551 p. 
DIEGUES, A.C.S. O mito moderno da natureza intocada. 2. ed. São Paulo: Ed. Hucitec, 1996. 169 p.

. As áreas naturais protegidas, o turismo e as populações tradicionais. In SERRANO, C.; BRUHNS, H.T. (Org.). Viagens à natureza: turismo, cultura e ambiente. 4. ed. Campinas: Ed. Papirus. 2001. p. 85-102.

FEATHERSTONE, M. Cultura de consumo e modernidade. Rio de Janeiro: Ed. Contraponto, 1995. $223 \mathrm{p}$.

FÓRUM INTERNACIONAL ONGs. Tratado de Educação Ambiental para sociedades sustentáveis e responsabilidade global. Rio de Janeiro, 1992. 7 p.

FREIRE, P. Pedagogia da indignação: cartas pedagógicas e outros escritos. São Paulo: Ed. UNESP, 2000. 134 p.

. Pedagogia do oprimido. 30. ed. São Paulo: Paz e Terra, 2001.184 p.

Pedagogia da autonomia: saberes necessários à prática educativa. 22. ed. Edição. São Paulo: Paz e Terra. 2002.165 p.

FREITAG, B. A teoria crítica ontem e hoje. São Paulo: Ed. Brasiliense, 2004. 184 p.

GUATTARI, F. As três ecologias. 12. ed. Campinas: Papirus. 2001. 56 p.

HALL, S. A identidade na pós-modernidade. 4. ed. Rio de Janeiro: MJ Livros, 2000. $102 \mathrm{p}$.

HARVEY, D. A condição pós-moderna. 12. ed. São Paulo: Edições Loyola, 2003. $349 \mathrm{p}$.

HINTZE, H. Guia de turismo: formação e perfil profissional. São Paulo: Ed. Roca, 2007. $146 \mathrm{p}$.

HOUAISS, A. Dicionário - Houaiss de língua Portuguesa. Rio de Janeiro: Objetiva, 2001.

HOBSBAWM, E. A era dos extremos: o breve século XX 1914-1991. São Paulo: Cia das Letras,1998. 598 p.

JAPPE, A. Guy Debord. Rio de Janeiro: Ed. Vozes, 1999. 272 p.

KIRK, A. A desobediência civil de Henry Thoreau. São Paulo: Jorge Zahar Editora, $2008127 \mathrm{p}$.

KRIPPENDORF, J. Sociologia do turismo: para uma nova compreensão do lazer e das viagens. 3. ed. São Paulo: Ed. Aleph, 2006. 184 p. 
Hintze, H.C.

LABATE. B.C. A experiência do "viajante-turista" na contemporaneidade. In: SERRANO, C.; BRUHNS, H.; LUCHIARI, M.T. (Org.). Olhares contemporâneos sobre o turismo. Campinas: Papirus Editora, 2000. p. 55-80

LENOBLE, R. História da ideia de natureza. Lisboa: Edições 70, 1990. 378 p.

LUKÁCS, G. Historia e consciência de classe: estudo de dialética marxista. 2. ed. Rio de Janeiro: Editora Elfos; Porto: Publicações Escorpião, 1989. 276 p.

LUCHIARI, M.T.D.P. Turismo, natureza e cultura caiçara: um novo colonialismo? In: SERRANO, C.M. Viagens à natureza: turismo, cultura e ambiente. 4. ed. São Paulo: Ed. Papirus, 2001. p. 59-84.

MENDONÇA, R. Conservar e criar: natureza, cultura e complexidade. São Paulo: Ed. SENAC, 2005. $255 \mathrm{p}$.

. EDUCAÇÃO AMBIENTAL e ecoturismo. In: MENDONÇA, R.; NEIMAN, Z. Ecoturismo no Brasil. São Paulo: Ed. Senac, 2005. p. 154-169.

MENDONÇA, R.; NEIMAN, Z. À sombra das árvores: transdisciplinaridade e Educação Ambiental em atividades extraclasse. São Paulo: Ed. Chronos, 2003. 127 p.

MORIN, E. Cultura de massas no século XX: neurose. 9. ed. Rio de Janeiro: Forense Universitária, 2000. 204 p.

. Os sete saberes necessários à educação do futuro. 8. ed. São Paulo: Ed. Cortez; Brasília: UNESCO, 2003. 118 p.

. O método: a humanidade da humanidade. Porto Alegre: Ed. Sulina. 2007. 309 p.

NOBRE, C. Os fundadores do pensamento: o marxismo da teoria crítica. São Paulo: Cultura Marcas, 2005. 1 DVD

NOBRE, M.; AMAZONAS, MC. Desenvolvimento sustentável: a institucionalização de um conceito. Brasília: Edições IBAMA, 2002. 367 p.

ORGANIZAÇÃO MUNDIAL DO TURISMO. Guia de desenvolvimento do turismo sustentável. Porto Alegre: Bookman, 2003. 168 p.

OURIQUES, H.R. A produção do turismo: fetichismo e dependência. Campinas: Ed. Alínea, 2005. 159 p.

OVALLES, O.; VIEZZER, M Manual latino americano de Educação Ambiental. São Paulo: Gaia, 1995. 192 p.

PIRES, P.S. Dimensões do ecoturismo. São Paulo: Ed. SENAC, 2002. 272 p.

. Entendendo o ecoturismo. In: TRIGO, L.G.G. Análises regionais e globais do turismo brasileiro. São Paulo: Ed. ROCA. 2005. p. 483-494. 
Ecoturismo na cultura de consumo: possibilidade de Educação Ambiental ou espetáculo?

RAMOS, M.V. Aventura e turismo de aventura: faces mutantes. In: TRIGO, L.G.G. Análises regionais e globais do turismo brasileiro. São Paulo: Ed. Roca, 2005. p. 469479

RODRIGUES, A.M. Desenvolvimento sustentável e atividade turística. In: SERRANO, C.; BRUHNS, H.; LUCHIARI, M.T. (Org.). Olhares contemporâneos sobre o turismo. Campinas: Papirus Ed., 2000. p. 171-188.

ROSE, A.T. Turismo planejamento e marketing. São Paulo: Ed. Manole, 2002. 152 p.

SALGUEIRO, V. Grand tour: uma contribuição à história do viajar por prazer e por amor à cultura. Revista Brasileira de História, São Paulo, 2002, v. 22, n. 44, p. 289-310,

SANTOS, B.S. Um discurso sobre as ciências. São Paulo: Ed. Cortez, 2003. 92 p.

SANTOS, M. Por uma outra globalização: do pensamento único a consciência universal. São Paulo: EDUSP, 2000. 174 p.

SÃO PAULO. Secretaria do Meio Ambiente. Resolução no. 32 de 31 de Março de 1998. Disponível em: <http://www.mma.gov.br>. Acesso em: 10 jul. 2006.

SERRANO, C.A. Educação pelas pedras: uma introdução. In: (Org.). A educação pelas pedras: ecoturismo e Educação Ambiental. São Paulo: Ed. Chronos, 2000. p. 7-24.

. O produto ecoturístico. In: ANSARAH, M.G.R. (Org.). Turismo como ensinar, como aprender. São Paulo: Ed. SENAC, 2001. p. 203-234.

SERRANO, C.A.; BRUHNS, H.T. (org.) Viagens à natureza: turismo, cultura e ambiente. 4. ed. Campinas: Ed. Papirus. 2001. 150 p

SEVERINO, A.J. Metodologia do trabalho científico. 21. ed. São Paulo: Cortez, 2000. 279 p.

SWARBROOKE, J. Turismo sustentável: conceitos e impacto ambiental. 3. ed. São Paulo: Ed. Aleph, 2000a. v. 1, 140 p.

Turismo sustentável: turismo cultural, ecoturismo e ética. 3. ed. São Paulo: Ed. Aleph, 2000b. v. 5, 140p.

THOMAS, K. O homem e o mundo natural: mudanças de atitude em relação às plantas e aos animais, 1500-1800. São Paulo: Cia das Letras, 1988. 454 p.

THOREAU, H.D. Walden ou a vida nos bosques e a desobediência civil. São Paulo: Ed. Aquariana, 2001. 346 p.

WEARING, S.; NEIL J. Ecoturismo: impactos, potencialidades e possibilidades. 1a edição brasileira. São Paulo: Manole, 2001. 256 p. 
Hintze, H.C.

\section{Notas}

${ }^{1}$ Este artigo foi escrito tomando por base a dissertação apresentada ao Programa de Mestrado em Ecologia Aplicada da Universidade de São Paulo - Escola Superior de Agricultura "Luiz de Queiroz" / Centro de Energia Nuclear na Agricultura sob orientação do professor Doutor Antonio Ribeiro de Almeida Junior em 12/09/2008. Procuramos nos manter fiéis ao texto original dentro dos limites desta publicação.

${ }^{2}$ Em suas pesquisas sobre a produção acadêmica a respeito do turismo no Brasil, o professor Ouriques (2005) identifica quatro linhas de interpretação e análise (correntes liberal, planejamento estatal, pós-moderna e a crítica) e afirma que há uma hegemonia no tratamento do assunto com a "massificação de um discurso dominante, ideologicamente pró-turístico, absorvido sem nenhuma análise em pesquisas acadêmicas" (OURIQUES, 2005, p. 69-70), que apresenta carências fundamentais por não considerar modelos analíticos que considerem a complexidade do tema.

${ }^{3}$ Conferir HOBSBAWM, E. A era dos extremos: o breve século XX 1914-1991. São Paulo: Cia das Letras. 1998, especialmente o capítulo 10 (A revolução social - 194590) e o capítulo 11 (Revolução Cultural).

${ }^{4}$ Por conta do tema cultura ser muito amplo, apontamos aqui para aprofundamento na discussão consultar FREITAS, Mário e FLEURI, Reinaldo. Conceito de complexidade: Uma contribuição para a formulação de princípios epistemológicos de uma educação intercultural, ambiental e para o desenvolvimento sustentável. Disponível em: www.rizoma3.ufsc.br/textos/332.pdf.

${ }^{5}$ Embora o Grand Tour tenha contribuído neste sentido, ele é essencialmente diferente do turismo, pois os grand tourists eram ricos aristocratas e suas viagens não tinham relação com o fruto de trabalho, nem eram realizadas naquilo que conhecemos atualmente por tempo livre (LABATE, 2000).

${ }^{6}$ Autor que pertence à corrente liberal de análise do turismo segundo as categorias de Ouriques (2005)

${ }^{7}$ A discussão referente aos impactos foi pensada tomando por base Serrano (2001, p. 216-217)

${ }^{8}$ As diretrizes para uma política nacional de Ecoturismo foram desenvolvidas pelo Governo Federal com colaboração do Grupo Interministerial composto pelos Ministérios da Indústria, do Comércio e do Turismo (desmembrado e extinto), do Meio Ambiente e Amazônia Legal, pelos Instituto Brasileiro do Meio Ambiente e Recursos Naturais Renováveis - IBAMA e pelo Instituto Brasileiro de Turismo - EMBRATUR (atualmente a EMBRATUR cuida exclusivamente da divulgação do Brasil no exterior e foi criado o 
Ministério do Turismo) e contou com a participação de várias Organizações Nãogovernamentais.

${ }^{9}$ BRASIL. Grupo de Trabalho interministerial MICT/MMA. Diretrizes para uma política nacional de Ecoturismo. Brasília: EMBRATUR, 1994. 48 p.

${ }^{10}$ Neste sentido, ainda, os teóricos afirmam que "o contato direto e de primeira mão com os ambientes naturais e com as manifestações ou aspectos culturais presentes no seu encontro possibilita aos turistas e visitantes uma oportunidade preciosa para desenvolver a percepção ambiental e assimilar conhecimentos que influenciarão decididamente na formação de uma consciência ecológica e cultural capaz de determinar posturas e atitudes diante do ambiente e da sociedade" (PIRES, 2005, p. 485).

${ }^{11}$ No entanto, ocorreu uma redução de sua proposta original que acabou por dar o tom verde à educação ambiental no caso específico do Brasil, pois surpreendentemente o MEC - Ministério da Educação e Cultura - ignorando a Conferência de Tbilisi, publicou o documento Ecologia - uma proposta para o ensino de 10 e 20 graus. Isso representou um retrocesso grotesco, dada a abordagem reducionista apresentada, na qual a Educação Ambiental ficaria acondicionada nos pacotes das ciências biológicas, como queriam os países industrializados, sem que se considerassem os demais aspectos da questão ambiental (sociais, culturais, econômicos, políticos, etc.), comprometendo o potencial analítico e reflexivo dos seus contextos - desde o local até o global - bem como o seu potencial catalítico-indutor de ações (DIAS, 2003, p. 83-84).

${ }^{12}$ Esta citação faz parte da palestra proferida por Paulo Freire na Jornada Pela Vida, na Eco-92, constante do livro de OVALLES, O.; VEIZZER, M. Manual latino americano de educação ambiental. São Paulo: Gaia. 1995.

${ }^{13}$ Optamos por assinalar as falas das entrevistas de maneira diferenciada quanto à formatação textual, colocando-as em fonte 10, com recuo de margem em dois pontos tanto à esquerda como à direita.

${ }^{14} \mathrm{O}$ Ministério do Turismo instituiu a figura deste profissional por meio da Lei 8623 de 28 de janeiro de 1993. É considerado Guia de Turismo, todo profissional que devidamente cadastrado no Ministério do Turismo exerça as funções de "acompanhar, orientar e transmitir informações a pessoas ou grupos, em visitas, excursões urbanas, municipais, estaduais, interestaduais, internacionais ou especializadas" (BRASIL, 1993). Deve exercer funções de coordenação e animação dos grupos de turistas, de socorrista além de atuar como interprete ambiental (HINTZE, 2007, p. 4-32). Embora seja a única profissão regulamentada do trade turístico tem diversos problemas em sua atuação, pois ainda "não se reconhece no Guia cadastrado um profissional capacitado para atuar nas mais diversas situações de uma viagem" (HINTZE, 2007, p. 113) 
Hintze, H.C.

${ }^{15}$ Para mais informações sobre o guia de turismo profissional, consultar HINTZE, H. Guia de turismo: formação e perfil profissional. São Paulo: Editora Roca, 2007. 146p. Este livro contém as informações acerca da profissão do guia de turismo e seu perfil profissional. Foi escrito entre 1999 e 2002 e apresenta uma abordagem técnica.

${ }^{16}$ Obviamente que o condutor de grupos deve estar totalmente atento às normas de segurança e às informações básicas do lugar, tais como clima, relevo, vegetação, fatos históricos etc.

${ }^{17}$ Os limites deste trabalho nos impedem de abordar as visitas à natureza daquelas pessoas que não necessitam da mediação de uma operadora turística, no entanto, reconhecemos como igualmente ricas tais oportunidades. Pensamos aqui justamente naquelas pessoas que ainda não se sentem à vontade para poder visitar ambientes naturais sem um devido acompanhamento, seja por desconhecimento dos locais, por medo de viajarem sozinhas, ou por quaisquer outros motivos.

${ }^{18}$ Debord faz várias referências implícitas a Marx no decorrer de seus textos.

${ }^{19} \mathrm{~A}$ ecologia profunda não separa seres humanos - ou qualquer outra coisa - do meio ambiente natural. Ela vê o mundo não como uma coleção de objetos isolados, mas como uma grande rede de fenômenos que estão fundamentalmente interconectados e são interdependentes. A ecologia profunda reconhece o valor intrínseco de todos os seres vivos e concebe os seres humanos apenas como um fio particular na teia da vida." (CAPRA, 1996, p. 25-26)

${ }^{20} \mathrm{Para}$ aprofundamento recomendamos a leitura das obras: ANSARAH. M.G.R. Turismo como ensinar, como aprender. São Paulo: Ed. SENAC, 2001. v. 2, 406 p.; BRASIL. Grupo de Trabalho Interministerial MICT/MMA. Diretrizes para uma política nacional de Ecoturismo. Brasília: EMBRATUR, 1994. 48 p.; CASCINO, F.A.; FIGUEIREDO, F. Comunidade e ecoturismo: outras leituras para a educação ambiental. In TRIGO, L.G.G. Análises regionais e globais do turismo brasileiro. São Paulo: Ed. ROCA. 2005. p. 547-554; SERRANO, C.M. Viagens à natureza: turismo, cultura e ambiente. 4. ed.. São Paulo: Ed. Papirus, 2001. p. 59-84.; MENDONÇA, R. Conservar e criar: natureza, cultura e complexidade. São Paulo: Ed. SENAC, 2005. 255 p.; MENDONÇA. R. Educação ambiental e ecoturismo. In: MENDONÇA, R.; NEIMAN, Z. Ecoturismo no Brasil. São Paulo: Ed. Senac, 2005. p. 154-169.; MENDONÇA, R.; NEIMAN, Z. À sombra das árvores: transdisciplinaridade e educação ambiental em atividades extraclasse. São Paulo: Ed. Chronos, 2003. 127 p.; PIRES, P.S. Dimensões do ecoturismo. São Paulo: Ed. SENAC, 2002. 272 p.; PIRES, P.S. Entendendo o ecoturismo. In: TRIGO, L.G.G. Análises regionais e globais do turismo brasileiro. São Paulo: Ed. ROCA. 2005. p. 483-494.; SERRANO, C.; BRUHNS, H.; LUCHIARI, M.T. (Org.). Olhares contemporâneos sobre o turismo. Campinas: Papirus Ed., 2000. p. 171-188.; SERRANO, C (Org.). A educação pelas pedras: ecoturismo e educação ambiental. São Paulo: Ed. Chronos, 2000. p. 7-24.; SERRANO, C. produto ecoturístico. In: ANSARAH, M.G.R. 
(Org.). Turismo como ensinar, como aprender. São Paulo: Ed. SENAC, 2001. p. 203234.; SERRANO, C.A.; BRUHNS, H.T. (org.) Viagens à natureza: turismo, cultura e ambiente. 4. ed. Campinas: Ed.Papirus. 2001.150 p; WEARING, S.; NEIL J. Ecoturismo: impactos, potencialidades e possibilidades. 1a edição brasileira. São Paulo: Manole, 2001. 256 p.

${ }^{21}$ Acreditamos que as entrevistas realizadas possam ser repetidas com outras operadoras para ampliar o quadro de debates.

${ }^{22}$ Reafirmando que este estudo dedica-se a considerar a variável educacional como diferencial entre o Ecoturismo e as demais formas de exploração turística. Outros fatores de diferenciação não estão sendo considerados como já fora apontado no texto.

Hélio César Hintze: ESALQ - Escola Superior de Agricultura Luiz de Queiroz; SENAC - Campus Águas de São Pedro; e Centro Universitário Hermínio Ometto (Uniararas)

Email: heliohintze@yahoo.com.br

Link para o currículo Lattes: http://lattes.cnpq.br/9514991193239586

Data de submissão: 31 de outubro de 2008

Data do aceite: 10 de janeiro de 2009 